\title{
The effect of $\left(\mathrm{NH}_{4}\right)_{2} \mathrm{SO}_{4}$ on the freezing properties of non-mineral dust ice nucleating substances of atmospheric relevance
}

Soleil E. Worthy ${ }^{1}$, Anand Kumar ${ }^{1}, \mathrm{Yu} \mathrm{Xi}^{1}{ }^{1}$, Jingwei Yun ${ }^{1}$, Jessie Chen ${ }^{1}$, Cuishan Xu ${ }^{1}$, Victoria E. Irish ${ }^{1}$, Pierre Amato ${ }^{2}$, Allan K. Bertram ${ }^{1}$

$5{ }^{1}$ Department of Chemistry, University of British Columbia, Vancouver, BC, V6T1Z1, Canada

${ }^{2}$ Institut de Chimie de Clermont-Ferrand, Université Clermont Auvergne, CNRS, Sigma-Clermont, 63000 Clermont-Ferrand, France

Abstract. A wide range of materials including mineral dust, soil dust, and bioaerosols have been shown to act as ice nuclei in the atmosphere. During atmospheric transport, these materials can become coated with inorganic and organic solutes which may impact their ability to nucleate ice. While a number of studies have investigated the impact of solutes at low concentrations on ice nucleation by mineral dusts, very few studies have examined their impact on non-mineral dust ice nuclei. We studied the effect of dilute $\left(\mathrm{NH}_{4}\right)_{2} \mathrm{SO}_{4}$ solutions on immersion freezing of a variety of non-mineral dust ice nucleating substances including bacteria, fungi, sea ice diatom exudates, sea surface microlayer, and humic substances using the droplet freezing technique. We also studied the effect of $\left(\mathrm{NH}_{4}\right)_{2} \mathrm{SO}_{4}$ on immersion freezing of mineral dust particles for comparison purposes. $\left(\mathrm{NH}_{4}\right)_{2} \mathrm{SO}_{4}$ had no effect on the median freezing temperature of nine of the ten tested non-mineral dust materials. There was a small but statistically significant decrease in the median freezing temperature of the bacteria $X$. campestris (change in median freezing temperature $\Delta T_{50}=-0.43 \pm 0.19{ }^{\circ} \mathrm{C}$ ) in the presence of $\left(\mathrm{NH}_{4}\right)_{2} \mathrm{SO}_{4}$ compared to pure water. Conversely, $\left(\mathrm{NH}_{4}\right)_{2} \mathrm{SO}_{4}$ increased the median freezing temperature of four different mineral dusts (Potassium-rich feldspar, Arizona Test Dust, Kaolinite, Montmorillonite) by $3{ }^{\circ} \mathrm{C}$ to $8{ }^{\circ} \mathrm{C}$. This significant difference in the response of mineral dust and non-mineral dust ice nucleating substances when exposed to $\left(\mathrm{NH}_{4}\right)_{2} \mathrm{SO}_{4}$ suggests that they nucleate ice and/or interact with $\left(\mathrm{NH}_{4}\right)_{2} \mathrm{SO}_{4}$ via different mechanisms. This difference suggests that the relative importance of mineral dust to non-mineral dust particles for ice nucleation in mixed-phase clouds could increase as these particles become coated with ammonium sulfate in the atmosphere. This difference also suggests that the addition of $\left(\mathrm{NH}_{4}\right)_{2} \mathrm{SO}_{4}$ to atmospheric samples of unknown composition could be used as an indicator or assay for the presence of mineral dust ice nuclei.

\section{Introduction}

Ice can form homogenously in the atmosphere at temperatures $\lesssim-35{ }^{\circ} \mathrm{C}$ (Koop and Murray, 2016) or heterogeneously at

30 warmer temperatures when an ice nucleating substance (INS) is present to initiate freezing (Murray et al., 2012; Kanji et al., 2017; Hoose and Möhler, 2012). Heterogeneous ice nucleation can take place via several different modes: immersion 
freezing, deposition nucleation, pore-condensation freezing, and contact freezing (Vali et al., 2015; David et al., 2019). Here we study immersion freezing, which involves the initiation of ice formation by an INS immersed in an aqueous droplet (Vali et al., 2015). This mechanism is thought to dominate ice formation in mixed-phase clouds (Ansmann et al., 2009; Westbrook and Illingworth, 2011).

Atmospheric INSs include mineral dust, soil dust, and bioaerosols (Murray et al., 2012; Kanji et al., 2017; Hoose and Möhler, 2012; Tang et al., 2016). While in the atmosphere, INSs can be transported over long distances and coated with organic and inorganic solutes (Burrows et al., 2009; Fröhlich-Nowoisky et al., 2016; Hinz et al., 2005; Tinsley et al., 2000;

40 McNaughton et al., 2009; Usher et al., 2003; Falkovich et al., 2004). Therefore, to effectively predict ice nucleation in the atmosphere, the effects of solutes on the freezing properties of INSs in the immersion mode need to be determined. A better understanding of the effects of solutes on freezing properties may also lead to a better understanding of the mechanism of heterogeneous ice nucleation in general, which remains highly uncertain (Coluzza et al., 2017). Additionally, if different INS-solute combinations produce known and unique changes in freezing properties, it may be possible to use freezing responses to solute additions as "fingerprints" for different INSs in atmospheric samples, as suggested by Reischel and Vali (1975).

Solutes can decrease the ice nucleating ability of INSs in the immersion mode by lowering the water activity in the solution (i.e. freezing point depression) (Rigg et al., 2013; Koop et al., 2000; Koop and Zobrist, 2009; Zobrist et al., 2008). Solutes can also modify the ice nucleating ability of an INS by interacting with and/or modifying its surface, even at low solute concentrations $(<0.1 \mathrm{M})$. Several studies have investigated the effects of solutes at low concentrations on the freezing properties of mineral dusts in the immersion mode. Aqueous $\mathrm{NH}_{3}$ and $\mathrm{NH}_{4}^{+}$salts at low concentrations improve the ice nucleation ability of feldspars, micas, gibbsite, quartz, and kaolinite, and have little to no effect on the ice nucleation ability of amorphous silica particles (Kumar et al., 2019a, b, 2018; Reischel and Vali, 1975; Whale et al., 2018). In some cases, potassium salts improve the ice nucleation ability of feldspars depending on the concentration of the salts and the freezing temperature (Yun et al., 2020; Perkins et al., 2020). Lithium iodide was found to increase the freezing temperature of kaolinite particles in one study (Reischel and Vali, 1975), but not in a more recent study (Ren et al., 2020). Other inorganic salts including, $\mathrm{NaOH}$ and $\mathrm{NaCl}$, decrease the freezing temperatures of some types mineral dusts (Kumar et al., 2019a, 2018, 2019b; Reischel and Vali, 1975; Whale et al., 2015). Inorganic acids either decrease the ice nucleation ability of mineral dust particles or have little effect, depending on the type of acid, exposure time, concentration of the acid, and type of mineral dust (Kumar et al., 2018; Burkert-Kohn et al., 2017; Sullivan et al., 2010b; Tobo et al., 2012; Augustin-Bauditz et al., 2014; Wex et al., 2014; Sullivan et al., 2010a; Link et al., 2020). On the other hand, organic solutes have often been found to have no effect on the ice nucleating ability of mineral dust particles (Zobrist et al., 2008; Koop and Zobrist, 2009; Tobo et al., 2012; Wex et al., 2014; Kanji et al., 2019). 
In comparison to mineral dust, there have only been a small number of studies that have investigated the effect of solutes at low concentrations on non-mineral dust INSs. Reischel and Vali (1975) studied the effects of a range of inorganic salts on the freezing properties of leaf derived nuclei and found only small changes (less than $1.5^{\circ} \mathrm{C}$ ) in the freezing temperatures of this INS in the presence of each of the tested solutes. Whale et al. (2018) studied the effects of $\left(\mathrm{NH}_{4}\right)_{2} \mathrm{SO}_{4}$ and $\mathrm{NaCl}$ on the ice nucleation ability of humic acid and found no significant change in freezing temperature in the presence of either solute. Attard et al. (2012) studied the effect of $\mathrm{pH}$ on the freezing properties of several Pseudomonas strains, and found that acidic solutions decreased the ice nucleation activity of the Pseudomonas strains studied. Koop and Zobrist (2009) studied the effects of the solutes $\left(\mathrm{NH}_{4}\right)_{2} \mathrm{SO}_{4}$, glucose, $\mathrm{H}_{2} \mathrm{SO}_{4}$, and PEG400 on the freezing properties of Snomax (a commercial product for artificial snow production made from components of Pseudomonas syringae) and found no effect of the solutes on the

75 freezing temperature other than freezing point depression. Chernoff and Bertram (2010) studied the effects of $\mathrm{H}_{2} \mathrm{SO}_{4}$ coatings on the freezing properties of Snomax and similarly found that the coating caused no significant change in the ice nucleating properties other than freezing point depression. Amato et al. (2015) injected Pseudomonas syringae suspensions in $\left(\mathrm{NH}_{4}\right)_{2} \mathrm{SO}_{4}$ into a cloud simulation chamber and observed a slight decrease in the ice nucleating activity compared to the cells in water, although these data were not corrected for freezing point depression by the solute. Weng et al. (2016) studied

80 the effects of the cryoprotectants ethylene glycol, propylene glycol, and trehalose on Pseudomonas syringae and found no effect of the solutes on freezing temperature other than freezing point depression. Desnos et al. (2020) studied the effects of the cyroprotectant $\mathrm{Me}_{2} \mathrm{SO}$ on the freezing properties of Snomax and observed a decrease in the ice nucleation activity that was greater than that produced by freezing point depression. Schwidetzky et al. (2021) studied the effect of the inorganic salts $\mathrm{NaCl}, \mathrm{NH}_{4} \mathrm{Cl}, \mathrm{NaSCN}, \mathrm{MgSO}_{4}$ on Snomax and found that $\mathrm{NaSCN}$ and $\mathrm{NH}_{4} \mathrm{Cl}$ decreased the freezing temperature of

85 Snomax, $\mathrm{NaCl}$ had no effect on the freezing temperature, and $\mathrm{MgSO}_{4}$ increased the freezing temperature of Snomax.

To expand on the limited studies mentioned above, we investigated the effect of $\left(\mathrm{NH}_{4}\right)_{2} \mathrm{SO}_{4}$ at a low concentration $(0.05 \mathrm{M})$ on the freezing properties of several types of non-mineral dust INSs of atmospheric relevance. $\left(\mathrm{NH}_{4}\right)_{2} \mathrm{SO}_{4}$ was chosen because it is a common inorganic solute in the atmosphere. This concentration $(0.05 \mathrm{M})$ was chosen because it is relevant for mixed phase clouds in the atmosphere. Because $\left(\mathrm{NH}_{4}\right)_{2} \mathrm{SO}_{4}$ causes an increase in the ice nucleation ability of most mineral dust particles even at low concentrations, we investigated whether it would have a similar effect on non-mineral dust INSs in the immersion mode. If $\left(\mathrm{NH}_{4}\right)_{2} \mathrm{SO}_{4}$ has little to no effect on the freezing properties of non-mineral dust INSs, then a change in freezing temperatures of atmospheric samples in response to the addition of low concentrations of $\left(\mathrm{NH}_{4}\right)_{2} \mathrm{SO}_{4}$ could potentially be used to identify the presence of mineral dust INSs in atmospheric samples. 


\section{Experimental}

\subsection{INS suspensions}

We investigated the effect of $\left(\mathrm{NH}_{4}\right)_{2} \mathrm{SO}_{4}$ on the ice nucleating ability of a range of non-mineral dust INSs of atmospheric relevance. INSs studied include bacteria, fungi, exudates from sea ice diatoms collected in Antarctica, INSs from the sea surface microlayer collected in the Arctic, and humic substances. For comparison purposes, we also investigated the effect of $\left(\mathrm{NH}_{4}\right)_{2} \mathrm{SO}_{4}$ on the ice nucleating ability of four types of mineral dust (Arizona Test Dust, K-rich feldspar, montmorillonite, and kaolinite). The effect of $\left(\mathrm{NH}_{4}\right)_{2} \mathrm{SO}_{4}$ on the ice nucleating ability of Arizona Test Dust, K-rich feldspar, and kaolinite, has been studied before (Kumar et al., 2018; Whale et al., 2018; Kumar et al., 2019b), but the effect on montmorillonite has not. Details of the studied INSs and how suspensions of the INSs were prepared are given below.

\subsubsection{Bacteria}

105 Pseudomonas syringae ( $P$. syringae) has been identified in the atmosphere and is an extremely effective ice nuclei with ice nucleation temperatures as high as -3 to $-4{ }^{\circ} \mathrm{C}$ (Ahern et al., 2007; Amato et al., 2007; Lindemann et al., 1982; Maki et al., 1974). Strain 31R1 was provided by S. Lindow (Department of Plant and Microbial Biology, University of California, Berkley, U.S.A.). The ice nucleation ability of Strain 31R1 has been studied previously (Lindow et al., 1989; Möhler et al., 2008). This strain was grown in nutrient broth for 5 days at $26^{\circ} \mathrm{C}$ shaking at $225 \mathrm{rpm}$. After growth, the suspension was

110 diluted in ultrapure water to an optical density of $\sim 0.06$ at a wavelength of $600 \mathrm{~nm}$, which should be approximately equal to a cell number concentration of $\sim 1 \times 10^{8}$ cells $\mathrm{mL}^{-1}$. Ultrapure water refers to distilled water purified by a Millipore system to a resistivity $18.2 \mathrm{M} \Omega \cdot \mathrm{cm}$ at $25^{\circ} \mathrm{C}$.

Xanthomonas campestris (X. campestris) has been identified in cloud droplets (Vaïtilingom et al., 2012) and its ice 115 nucleating ability in the immersion mode has been previously characterized (Joly et al., 2013; Kim et al., 1987). Strain 32b52 was provided by P. Amato (Institut de Chimie de Clermont-Ferrand CNRS-Clermont University, Aubière, France). The ice nucleation ability of this strain has been studied previously (Joly et al., 2013). This strain was grown in R2A broth for 2 days at $17{ }^{\circ} \mathrm{C}$ shaking at $225 \mathrm{rpm}$. After growth, the suspension was diluted to an optical density of $\sim 0.06$ which should be equivalent to a cell number concentration of $\sim 1 \times 10^{8}$ cells $\mathrm{mL}^{-1}$.

Snomax is a commercial product for artificial snow production made of proteins from $P$. syringae cells. The freezing ability of Snomax in the immersion mode has been characterized in several previous studies (Koop and Zobrist, 2009; Möhler et al., 2008; Whale et al., 2015; Wex et al., 2015). A 0.1 wt\% suspension of Snomax (Johnson Controls Snow) was prepared in ultrapure water leading to a cell concentration of $\sim 7 \times 10^{8}$ cells $\mathrm{mL}^{-1}$ (Möhler et al., 2008; Koop and Zobrist, 2009). 


\subsubsection{Fungi}

Fusarium acuminatum (F. acuminatum) and Fusarium avenaceum ( F. avenaceum) have been identified in the atmosphere and have been found to be effective INSs in the immersion mode (Amato et al., 2007; Hasegawa et al., 1994; Pouleur et al., 1992; Richard et al., 1996; Seifi et al., 2014). Cultures were obtained from the American Type Culture Collection (ATCC catalogue numbers 60315 and 200466 for F. acuminatum and F. avenaceum, respectively) and grown in potato dextrose broth for 3-4 days at approximately $21{ }^{\circ} \mathrm{C}$ shaking at $50 \mathrm{rpm}$. After growth, the suspensions were diluted to a cell number concentration on the order of $10^{6}$ cells $\mathrm{mL}^{-1}$ in ultrapure water based on optical density at a wavelength of $530 \mathrm{~nm}$ (Petrikkou et al., 2001).

\subsubsection{Exudates from sea-ice diatoms collected in Antarctica}

Recent studies have shown that marine diatoms and their exudates can act as effective ice nuclei (Alpert et al., 2011; Knopf et al., 2011; Ladino et al., 2016; Wang et al., 2015; Wilson et al., 2015; Ickes et al., 2020). In a recent study we showed that exudates from sea-ice diatoms collected in Antarctica also contain INSs (Xi et al., 2021). After melting of sea ice, these INSs can be transferred to the atmosphere by the bubble bursting mechanism (Blanchard, 1964). Here we used a sample of exudates from dense sea-ice diatom communities consisting of material collected at Tent Island $\left(77^{\circ} 41^{\prime} 7.90^{\prime \prime S}, 166^{\circ} 25^{\prime} 14.62^{\prime \prime E}\right)$ and Inaccessible Island $\left(77^{\circ} 40^{\prime} \mathrm{S}, 166^{\circ} 22^{\prime} \mathrm{E}\right)$ in November 1998 (Raymond, 2000). The

140 sample was originally collected to study the ice binding properties of exudates from sea-ice diatoms (Raymond, 2000). Chunks of brown ice containing sea-ice diatoms were collected from the underside of sea ice. Antarctic sea ice at the icewater interface can become brown as a result of the growth of dense diatom communities (Grossi et al., 1987), hence brown ice was specifically collected. The collected brown ice was rich in diatoms and contained few other organisms based on visual inspection with a dissecting microscope. The chunks of brown ice were melted and the diatom cells were allowed to

145 settle overnight. The supernatant of the sample, which contained the diatom exudates, was then subjected to two cycles of ice-affinity purification to isolate ice binding substances in the supernatants (Raymond and Fritsen, 2001; Raymond, 2000). In each cycle of ice affinity purification, the sample containing ice binding materials was half frozen at $-5{ }^{\circ} \mathrm{C}$ and the ice was harvested (Raymond, 2000). This process, which was carried out directly after sampling, concentrated ice binding materials in the sample. After purification, the sample was stored at $-20^{\circ} \mathrm{C}$ until use.

\section{$150 \quad$ 2.1.4 Sea surface microlayer collected in the Arctic}

The sea surface microlayer (SML), which has a thickness of less than $1 \mathrm{~mm}$, is defined as the interface between the ocean and atmosphere (Liss and Duce, 1997) and has been shown to contain ice nucleating substances (Wilson et al., 2015; Irish et al., 2017, 2019; Mccluskey et al., 2018; Wolf et al., 2020). INSs within this interface can be lofted into the atmosphere via the bubble bursting mechanism (Blanchard, 1964; Ickes et al., 2020; Mccluskey et al., 2018; DeMott et al., 2016). In a 155 previous study, we showed that SML samples collected in the eastern Arctic during the period of July and August 2016 
contained INSs (Irish et al., 2019). These INSs were most likely heat-labile biological materials of $<0.2 \mu \mathrm{m}$ in size (Irish et al., 2019). Two of the samples investigated in the study (microlayer sampling station 2 collected at $67^{\circ} 23.466^{\prime} \mathrm{N}$, $063^{\circ} 22.067^{\prime} \mathrm{W}$ and microlayer sampling station 7 collected at $77^{\circ} 47.213^{\prime} \mathrm{N}, 076^{\circ} 29.841^{\prime} \mathrm{W}$ ) were also used here. The microlayer samples were collected with the glass plate technique, where a glass plate was immersed into the water and withdrawn slowly and the microlayer that adhered to the glass plate was scraped off into a collection vessel as detailed in Irish et al. (2019). After collection samples were stored at $-80^{\circ} \mathrm{C}$.

\subsubsection{Humic and fulvic acid}

Humic acid and fulvic acid are mixtures of macromolecular organic compounds isolated from soils and water. Humic like substances contain multiple organic compounds that are abundant in soils and have been identified in atmospheric aerosol (Graber and Rudich, 2006; White, 2009). The ice nucleating abilities of humic and fulvic acid have been characterized in previous studies (Knopf et al., 2010; O’Sullivan et al., 2014; Pratt et al., 2009; Shilling et al., 2006; Borduas-Dedekind et al., 2019). A Suwanee River fulvic acid standard and a Leonardite humic acid standard were obtained from the International Humic Substances Society, and 0.1 wt \% solutions were prepared using ultrapure water.

\subsubsection{Mineral dust}

170 Arizona Test Dust (ATD) is a commercially available mineral dust that is often used as a proxy for mineral dust in the atmosphere. The ice nucleating ability of ATD has been characterized in several studies (Zobrist et al., 2008; Whale et al., 2018; Wheeler et al., 2015; Perkins et al., 2020; Kanji and Abbatt, 2010; Knopf and Koop, 2006). A 0.1 wt \% suspension of Arizona Test Dust (Powder Technology Inc, 0-3 $\mu \mathrm{m}$ size fraction) was prepared in ultrapure water and stirred overnight before freezing experiments to ensure even particle distribution.

Potassium-rich feldspar (K-rich feldspar) is an important component of atmospheric mineral dust. The ice nucleation ability of K-rich feldspar has been quantified previously (Peckhaus et al., 2016a; Atkinson et al., 2013; Whale et al., 2018; Yun et al., 2020; Harrison et al., 2016). A K-rich feldspar sample was obtained from the Pacific Museum of Earth, University of British Columbia, and ground into a powder using a mortar and pestle. We have characterized the ice nucleating ability of this specific power in a previous study (Yun et al., 2020). The mineralogy of the powder was $85 \%$ microcline $\left(\mathrm{KAlSi}_{3} \mathrm{O}_{8}\right)$ and $15 \%$ albite $\left(\mathrm{NaAlSi}_{3} \mathrm{O}_{8}\right)$ as determined by $\mathrm{X}$-ray diffraction measurements. The specific surface area of the particles after grinding was $0.75 \mathrm{~m}^{2} \mathrm{~g}^{-1}$ based on Brunauer-Emmet-Teller (BET) nitrogen adsorption method (Yun et al., 2020). A 0.1 wt\% suspension of this K-feldspar powder was prepared in ultrapure water and stirred overnight before freezing experiments to ensure even particle distribution.

Kaolinite is another mineral abundant in the atmosphere (Tang et al., 2016; Broadley et al., 2012; Kandler et al., 2007; Delany et al., 1967; Glaccum and Prospero, 1980). The ice nucleation ability of kaolinite has been previously characterized 
(Ren et al., 2020; Hoose and Möhler, 2012; Kumar et al., 2019b; Chernoff and Bertram, 2010; Pinti et al., 2012; Wex et al., 2014; Lüönd et al., 2010). A Kaolinite sample (KGa-1b) was obtained from the Clay Minerals Society, Purdue University.

The mineralogy of the sample was $94.7 \%$ kaolinite $\left(\mathrm{Al}_{2} \mathrm{Si}_{2} \mathrm{O}_{5}(\mathrm{OH})_{5}\right), 3.6 \%$ anatase $\left(\mathrm{TiO}_{2}\right)$, and $1.7 \%$ feldspar (orthoclase) as determined by X-ray diffraction measurements. A $1 \mathrm{wt} \%$ suspension of kaolinite was prepared in ultrapure water and stirred overnight before freezing experiments to ensure even particle distribution.

Montmorillonite is a mineral found in high abundance in African and Asian clay dusts (Tang et al., 2016; Glaccum and

Prospero, 1980; Prospero, 1999; Ganor, 1991). The ice nucleation ability of montmorillonite has been previously characterized (Eastwood et al., 2008; Salam et al., 2007; Hoose and Möhler, 2012; Chernoff and Bertram, 2010; Kulkarni et al., 2014; Kaufmann et al., 2016; Atkinson et al., 2013). A montmorillonite sample was obtained from ThermoFisher Scientific, -200 Mesh Powder. The sample was mined and crushed to 200 Mesh Powder and was not chemically processed. A $1 \mathrm{wt} \%$ suspension of montmorillonite was prepared in ultrapure water and stirred overnight before freezing experiments to ensure even particle distribution.

\subsection{Droplet freezing experiments}

The effects of $\left(\mathrm{NH}_{4}\right)_{2} \mathrm{SO}_{4}$ on the ice nucleating abilities of the INS samples were determined using the droplet freezing technique (Fig. 1a) (Whale et al., 2015; Vali, 1971). We have used this technique previously to study the ice nucleating properties of mineral dust, sea surface microlayer and bulk sea water, and exudates from diatoms (Xi et al., 2021; Yun et al., 2020; Irish et al., 2019). Three hydrophobic glass slides (Hampton Research HR3-239) were rinsed with ultrapure water, dried with nitrogen gas, and placed on a cold stage (Grant Asymptote EF600 Cryocooler). Twenty $1 \mu \mathrm{L}$ drops from an INS suspension were placed onto each slide using a micropipette. A second $1 \mu \mathrm{L}$ drop of either $0.1 \mathrm{M}\left(\mathrm{NH}_{4}\right)_{2} \mathrm{SO}_{4}$ or ultrapure water was added to each sample droplet with a micropipette, bringing the total volume of each droplet to $2 \mu \mathrm{L}$. The $0.1 \mathrm{M}$ $\left(\mathrm{NH}_{4}\right)_{2} \mathrm{SO}_{4}$ solution (Fischer Scientific $\left(\mathrm{NH}_{4}\right)_{2} \mathrm{SO}_{4}$, ACS grade) was prepared in ultrapure water. A chamber with an attached digital camera was placed over the droplets to isolate them from the ambient air. A small flow of ultrapure nitrogen gas $(0.2$ $\mathrm{L} \min ^{-1}$ ) was passed through the chamber to prevent condensation of water on the slides during cooling. The flow did not cause evaporation of the droplets or affect the freezing temperature of the droplets (Whale et al., 2015). The temperature of the cold stage was decreased at a rate of $3{ }^{\circ} \mathrm{C} \mathrm{min}^{-1}$ until all sample droplets were frozen. The digital camera attached to the chamber recorded videos of the freezing process. Examples of images recorded are shown in Fig. 1b-c. The video and temperature data from the cold stage were processed using a MATLAB script to determine the freezing temperature of each droplet (Xi et al., 2021). The uncertainty in the cold stage temperature measurements was approximately $\pm 0.25{ }^{\circ} \mathrm{C}$ according to the manufacturer specifications, which was verified by measuring the melting point of water and dodecane and comparing the measured melting points with literature values (Lide, 2001). 


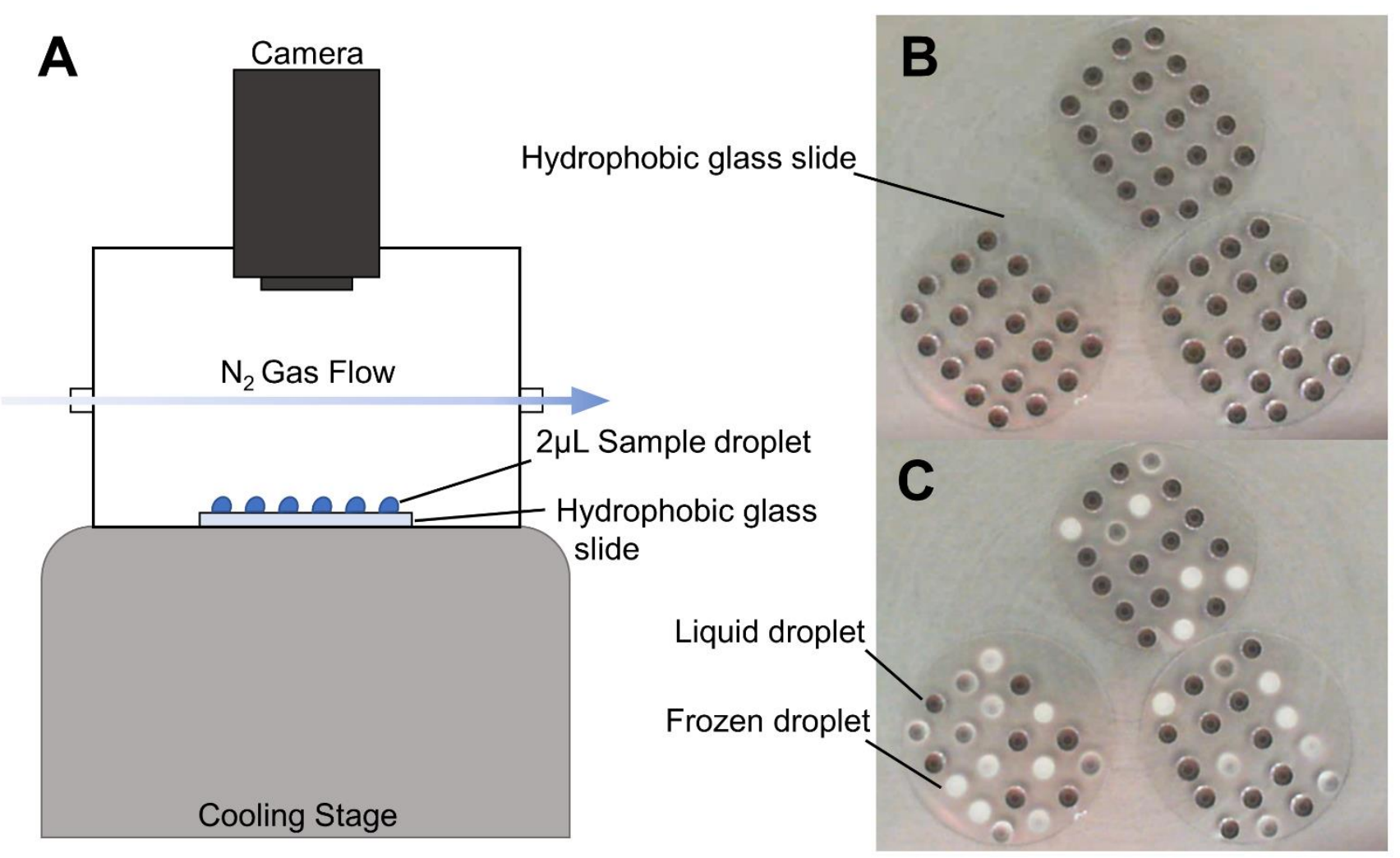

220 Figure 1. Experimental setup for droplet freezing experiments. A) Schematic of droplet freezing setup. Images taken by the digital camera during freezing experiments with $F$. avenaceum, taken at approximately $\mathrm{B})-3{ }^{\circ} \mathrm{C}$ and $\mathrm{C}$ ) $-\mathbf{1 1 . 5}{ }^{\circ} \mathrm{C}$, respectively. The diameter of each glass slide is $18 \mathrm{~mm}$.

In cases where $\left(\mathrm{NH}_{4}\right)_{2} \mathrm{SO}_{4}$ was added to the droplets in the freezing experiments, the freezing temperatures of the droplets were corrected for the freezing point depression caused by the solute using the following equation (Atkins and de Paula, 225 2014):

$\Delta T_{f}=i K_{f} m_{\text {solute }}$

where $\Delta T_{f}$ is the freezing point depression, $i$ is the van't Hoff factor, $K_{f}$ is the cryoscopic constant of water $\left(1.86{ }^{\circ} \mathrm{C} \cdot \mathrm{kg} \mathrm{mol}^{-}\right.$ ${ }^{1}$ ), and $m_{\text {solute }}$ is the molality of $\left(\mathrm{NH}_{4}\right)_{2} \mathrm{SO}_{4}$ in the $2 \mu \mathrm{L}$ droplets. For an $\left(\mathrm{NH}_{4}\right)_{2} \mathrm{SO}_{4}$ concentration of $0.05 \mathrm{M}$ (the concentration of $\left(\mathrm{NH}_{4}\right)_{2} \mathrm{SO}_{4}$ in the $2 \mu \mathrm{L}$ droplets) the calculated freezing point depression was $0.28{ }^{\circ} \mathrm{C}$. Heterogeneous

230 freezing temperatures reported here have been corrected for the freezing point depression caused by the addition of $\left(\mathrm{NH}_{4}\right)_{2} \mathrm{SO}_{4}$. 
https://doi.org/10.5194/acp-2021-245

Preprint. Discussion started: 25 March 2021

(c) Author(s) 2021. CC BY 4.0 License.

(c) (i)

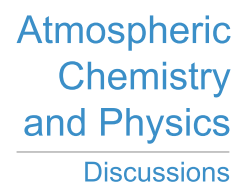

\section{Results and Discussion}

\subsection{Effects of $\left(\mathrm{NH}_{4}\right)_{2} \mathrm{SO}_{4}$ on ice nucleation ability of non-mineral dust INSs}

Shown in Fig. 2-5 are the fraction frozen curves for the $2 \mu \mathrm{L}$ droplets containing non-mineral dust INSs with and without $2350.05 \mathrm{M}\left(\mathrm{NH}_{4}\right)_{2} \mathrm{SO}_{4}$. Also shown in Fig. 2-5 are fraction frozen curves for laboratory blanks. For the bacteria and fungi grown in the laboratory, blanks correspond to the fraction frozen curves for the growth medium at the same dilution factor as in the INS suspensions. For all other cases, blanks correspond to fraction frozen curves of $2 \mu \mathrm{L}$ droplets of ultrapure water. On average, the fraction frozen curves for the INSs were shifted to warmer temperatures compared to the fraction frozen curves for the blanks (Fig. 2-5). As a result, we concluded the INSs were responsible for ice nucleation in our experiments. 

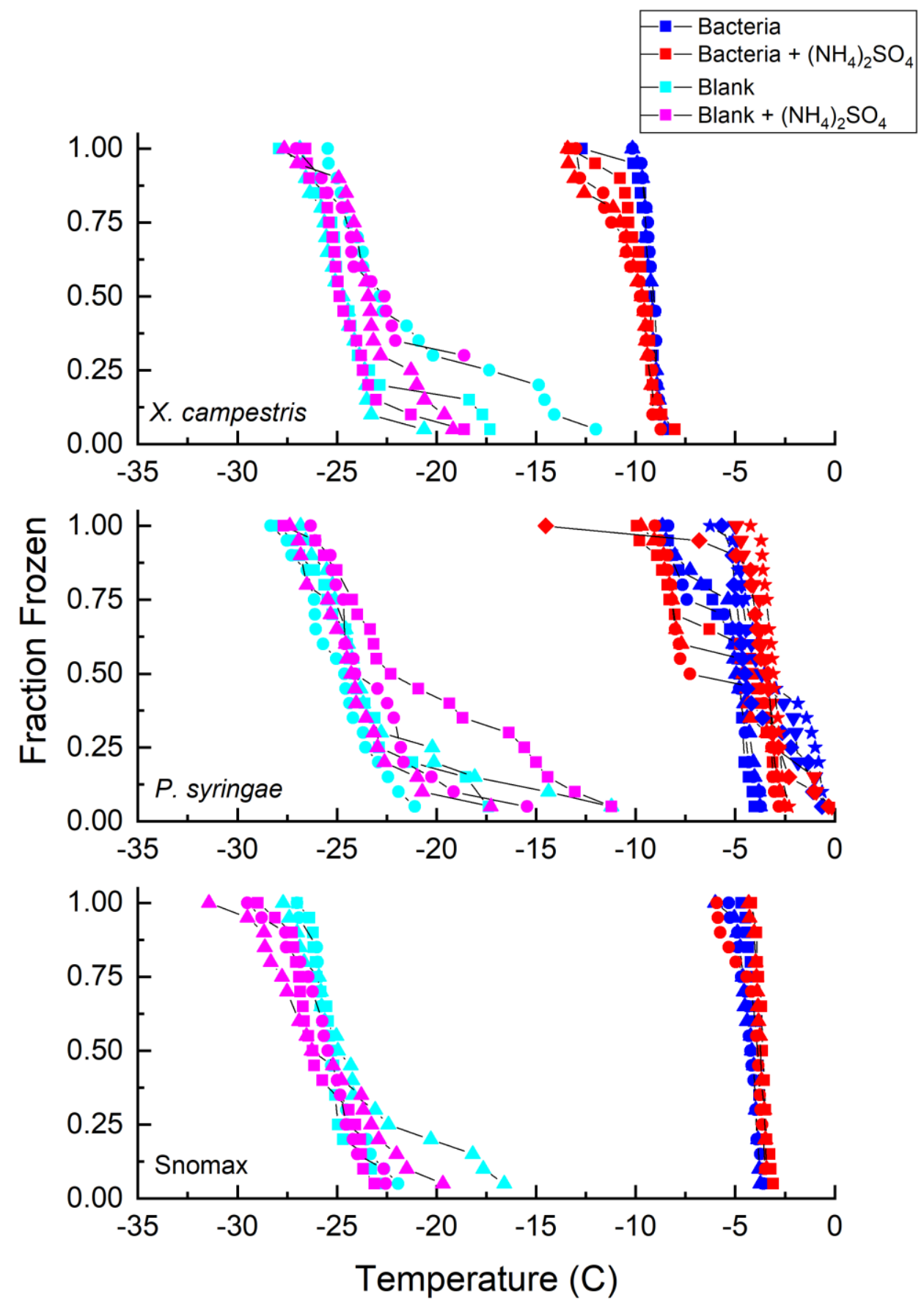

Figure 2. Fraction of droplets frozen as a function of temperature for samples of Xanthomonas campestris (top), Pseudomonas syringae (middle), and Snomax (bottom) with (red) and without (blue) $0.05 \mathrm{M}\left(\mathrm{NH}_{4}\right)_{2} \mathrm{SO}_{4}$ compared with the respective growth media (X. campestris, $P$. syringae) or ultrapure water (Snomax) control for each sample with (pink) and without (cyan) $0.05 \mathrm{M}$ $\left(\mathrm{NH}_{4}\right)_{2} \mathrm{SO}_{4}$. Different symbols with the same color represent different trials. Freezing data have been corrected for freezing point depression by $0.05 \mathrm{M}\left(\mathrm{NH}_{4}\right)_{2} \mathrm{SO}_{4}$. 


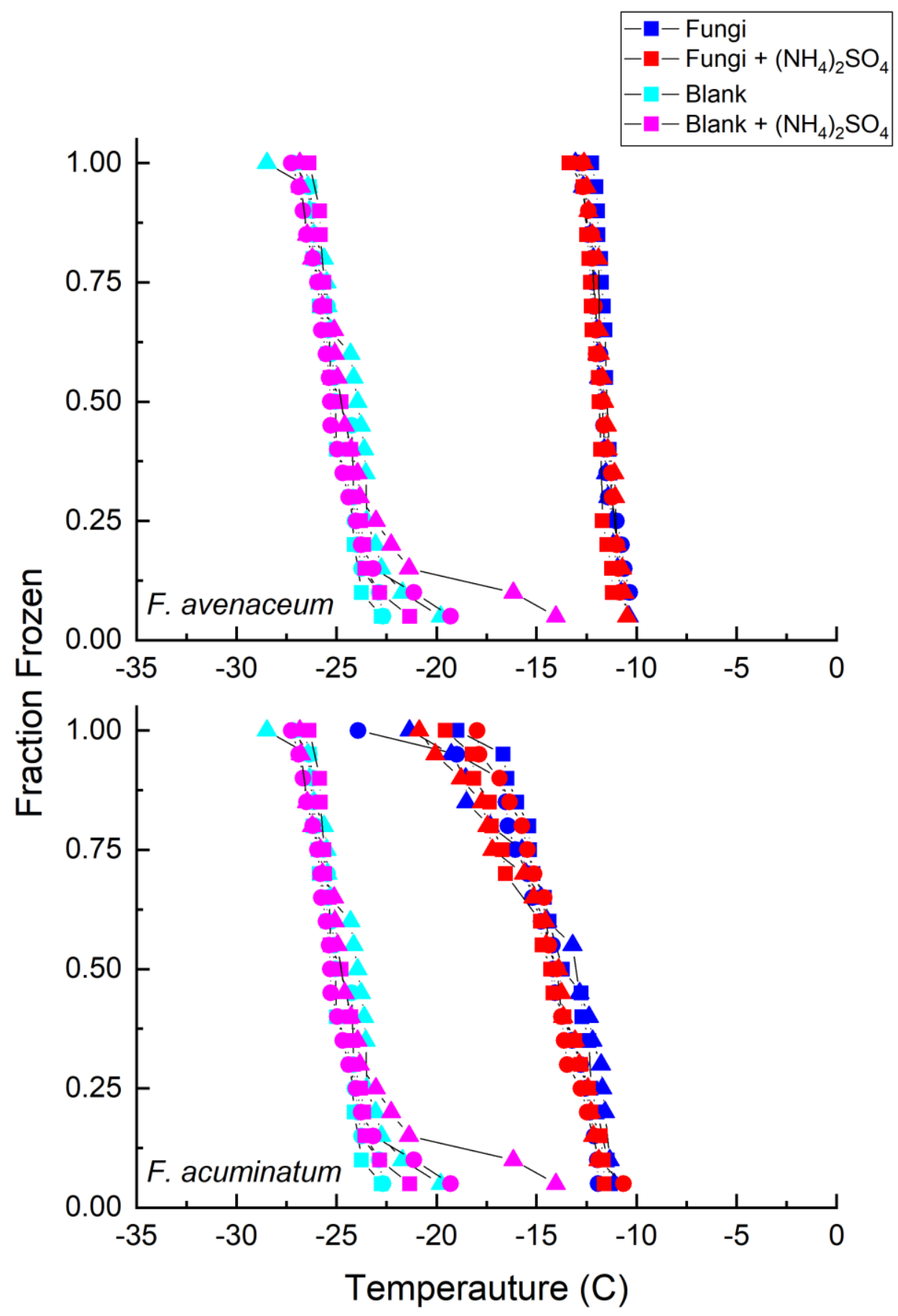

Figure 3. Fraction of droplets frozen as a function of temperature for samples of Fusarium avenaceum (top) and Fusarium acuminatum (bottom) with (red) and without (blue) $0.05 \mathrm{M}\left(\mathrm{NH}_{4}\right)_{2} \mathrm{SO}_{4}$ compared with a growth media control for each sample with (pink) and without (cyan) $0.05 \mathrm{M}\left(\mathrm{NH}_{4}\right)_{2} \mathrm{SO}_{4}$. Different symbols with the same color represent different trials. Freezing data have been corrected for freezing point depression by $0.05 \mathrm{M}\left(\mathrm{NH}_{4}\right)_{2} \mathrm{SO}_{4}$. 

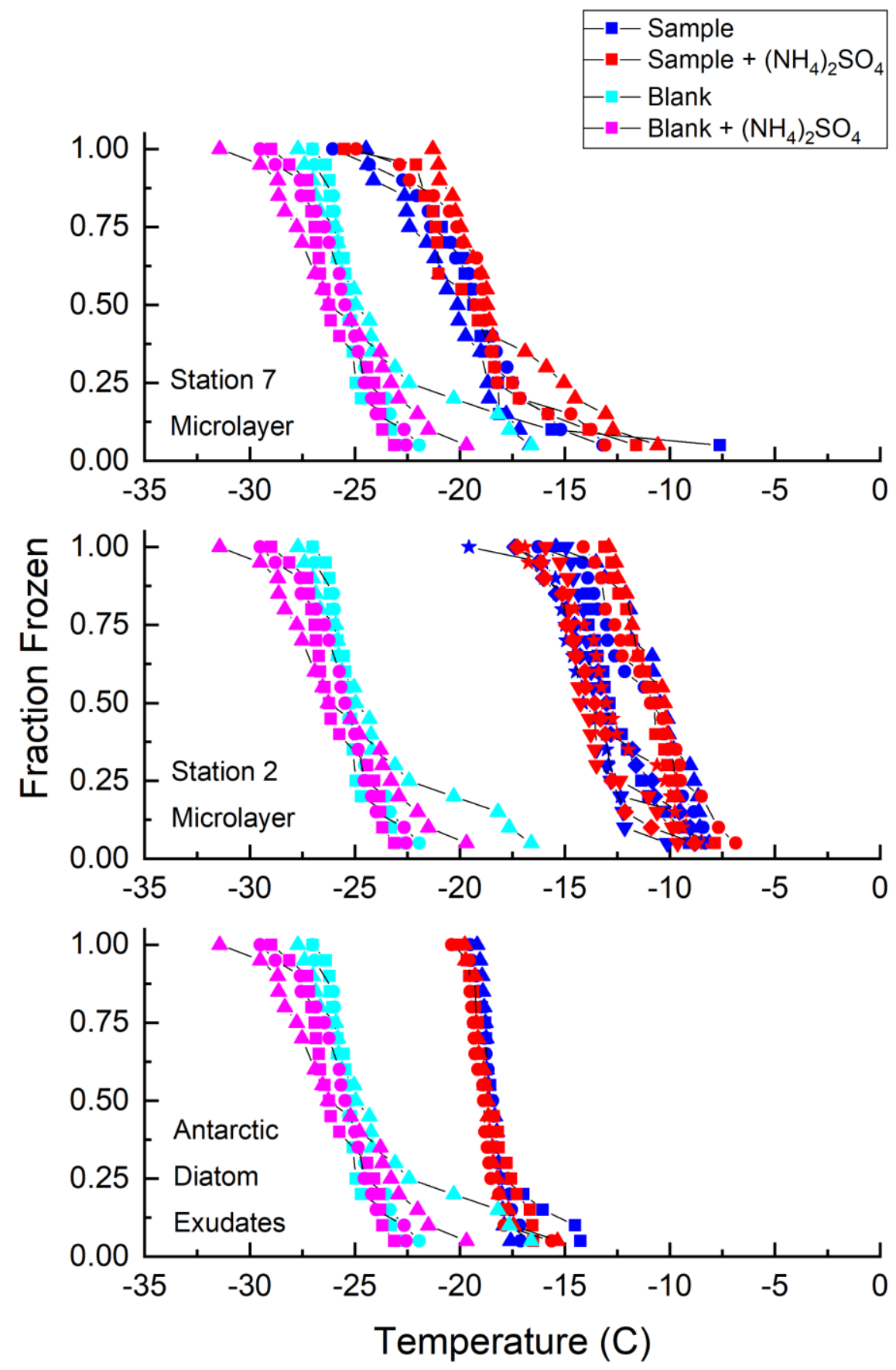

Figure 4. Fraction of droplets frozen as a function of temperature for samples of Arctic sea surface microlayer from Station 7 (top), Arctic sea surface microlayer from Station 2 (middle), and Antarctic diatom exudates collected from Tent Island/Inaccessible Island (red) and without (blue) $0.05 \mathrm{M}\left(\mathrm{NH}_{4}\right)_{2} \mathrm{SO}_{4}$ compared with an ultrapure water control for each sample with (pink) and without (cyan) $0.05 \mathrm{M}\left(\mathrm{NH}_{4}\right)_{2} \mathrm{SO}_{4}$. Different symbols with the same color represent different trials. Freezing data have been corrected for freezing point depression by $0.05 \mathrm{M}\left(\mathrm{NH}_{4}\right)_{2} \mathrm{SO}_{4}$. 


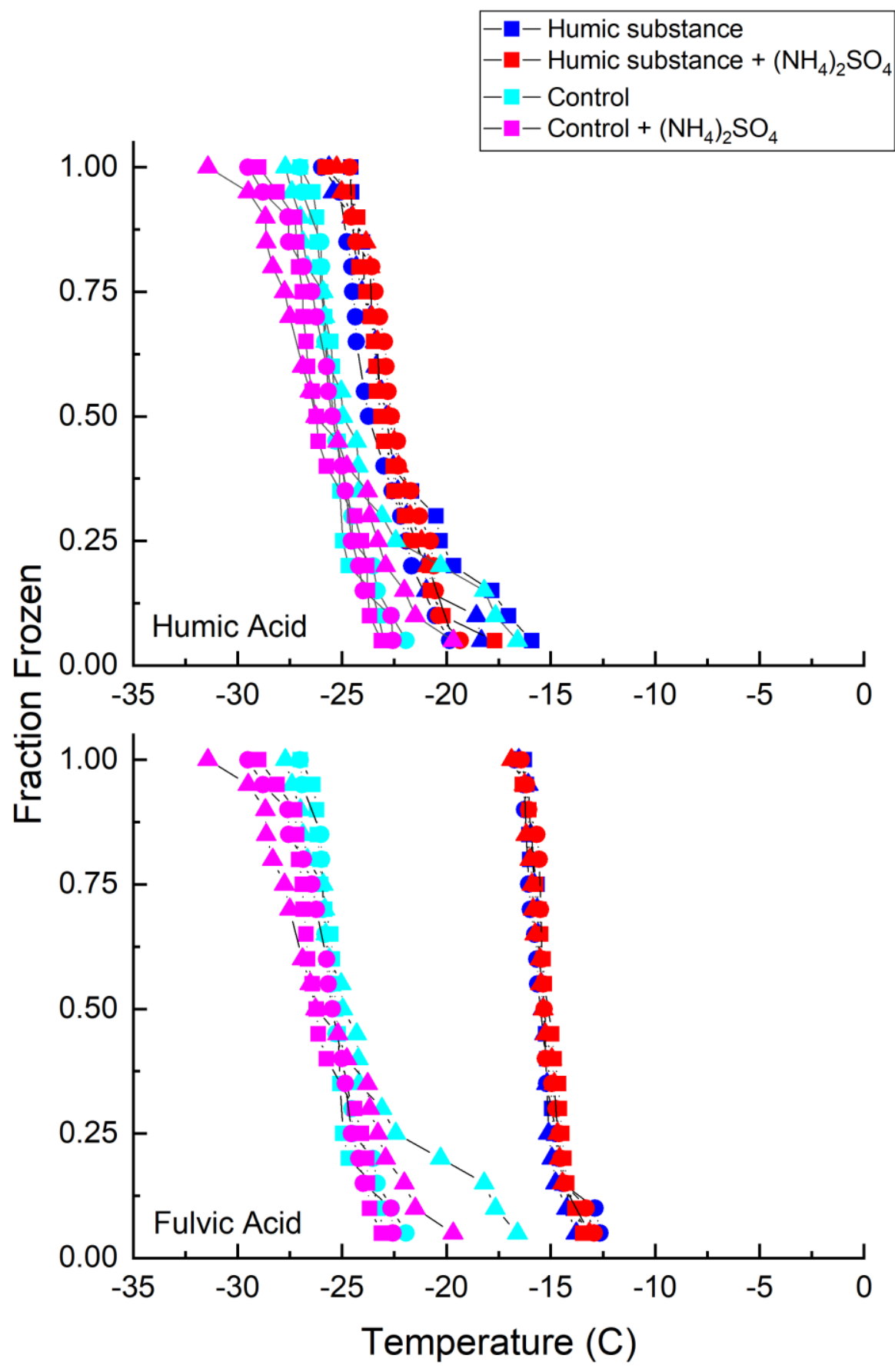

Figure 5. Fraction of droplets frozen as a function of temperature for samples of fulvic acid (top) and humic acid (bottom) with (red) and without (blue) $0.05 \mathrm{M}\left(\mathrm{NH}_{4}\right)_{2} \mathrm{SO}_{4}$ compared with an ultrapure water control for each sample with (pink) and without (cyan) $0.05 \mathrm{M}\left(\mathrm{NH}_{4}\right)_{2} \mathrm{SO}_{4}$. Different symbols with the same color represent different trials. Freezing data have been corrected for freezing point depression by $0.05 \mathrm{M}\left(\mathrm{NH}_{4}\right)_{2} \mathrm{SO}_{4}$. 
For all the non-mineral dust INSs, the fraction frozen curves in the presence of $\left(\mathrm{NH}_{4}\right)_{2} \mathrm{SO}_{4}$ overlap with the fraction frozen curves without $\left(\mathrm{NH}_{4}\right)_{2} \mathrm{SO}_{4}$ (Fig. 2-5). Furthermore, the shapes of the fraction frozen curves for droplets containing nonmineral dust INSs are very similar with and without $\left(\mathrm{NH}_{4}\right)_{2} \mathrm{SO}_{4}$. To better compare the effect of $\left(\mathrm{NH}_{4}\right)_{2} \mathrm{SO}_{4}$ on different INSs, we calculated the change in the median freezing temperature $\left(\Delta T_{50}\right)$ due to the presence of $\left(\mathrm{NH}_{4}\right)_{2} \mathrm{SO}_{4}$ using the following equation:

$\Delta T_{50}=T_{50,\left(\mathrm{NH}_{4}\right)_{2} \mathrm{SO}_{4}}-\mathrm{T}_{50, \mathrm{No}\left(\mathrm{NH}_{4}\right)_{2} \mathrm{SO}_{4}}$

where $T_{50,\left(\mathrm{NH}_{4}\right)_{2} \mathrm{SO}_{4}}$ is the median freezing temperature of the droplets containing an INS and $\left(\mathrm{NH}_{4}\right)_{2} \mathrm{SO}_{4}$ (after correcting for freezing point depression) and $T_{50, \mathrm{No}\left(\mathrm{NH}_{4}\right)_{2} \mathrm{SO}_{4}}$ is the median freezing temperature of droplets containing an INS without $\left(\mathrm{NH}_{4}\right)_{2} \mathrm{SO}_{4} . T_{50,\left(\mathrm{NH}_{4}\right)_{2} \mathrm{SO}_{4}}$ and $T_{50, \mathrm{No}\left(\mathrm{NH}_{4}\right)_{2} \mathrm{SO}_{4}}$ were averages of all replicates for a given INS suspension. Uncertainties in $\Delta T_{50}$ were calculated from the $95 \%$ confidence intervals for $T_{50,\left(\mathrm{NH}_{4}\right)_{2} \mathrm{SO}_{4}}$ and $T_{50, \mathrm{No}_{(}\left(\mathrm{NH}_{4}\right)_{2} \mathrm{SO}_{4}} \cdot \Delta T_{25}$ and $\Delta T_{75}$ values were calculated similarly and correspond to the change in the freezing temperatures evaluated at a fraction frozen of 0.25 and 0.75 , respectively.

For eight of the ten non-mineral dust INSs (Snomax, P. syringae, F. acuminatum, F. avenaceum, SML from station 2, SML from station 7, humic acid, and fulvic acid) $\Delta T_{50}, \Delta T_{25}$, and $\Delta T_{75}$ values were all less than the uncertainty in the measurements (95\% confidence interval), consistent with no change in freezing temperature upon adding $\left(\mathrm{NH}_{4}\right)_{2} \mathrm{SO}_{4}(\mathrm{Fig}$. 6). For $X$. campestris, a small statistically significant negative $\Delta T_{50}$ value was observed $\left(\Delta T_{50}=-0.43 \pm 0.19\right)$. For $X$. 280 campestris and the Antarctic diatom exudates, small statistically significant negative $\Delta T_{75}$ values were observed $\left(\Delta T_{75}=-\right.$ $1.27 \pm 1.13$ and $-0.40 \pm 0.34$ respectively). In no case was a statistically significant positive $\Delta T_{50}, \Delta T_{25}$, or $\Delta T_{75}$ observed, consistent with $\left(\mathrm{NH}_{4}\right)_{2} \mathrm{SO}_{4}$ either having no effect on or decreasing the ice nucleation ability of non-mineral dust INSs. 

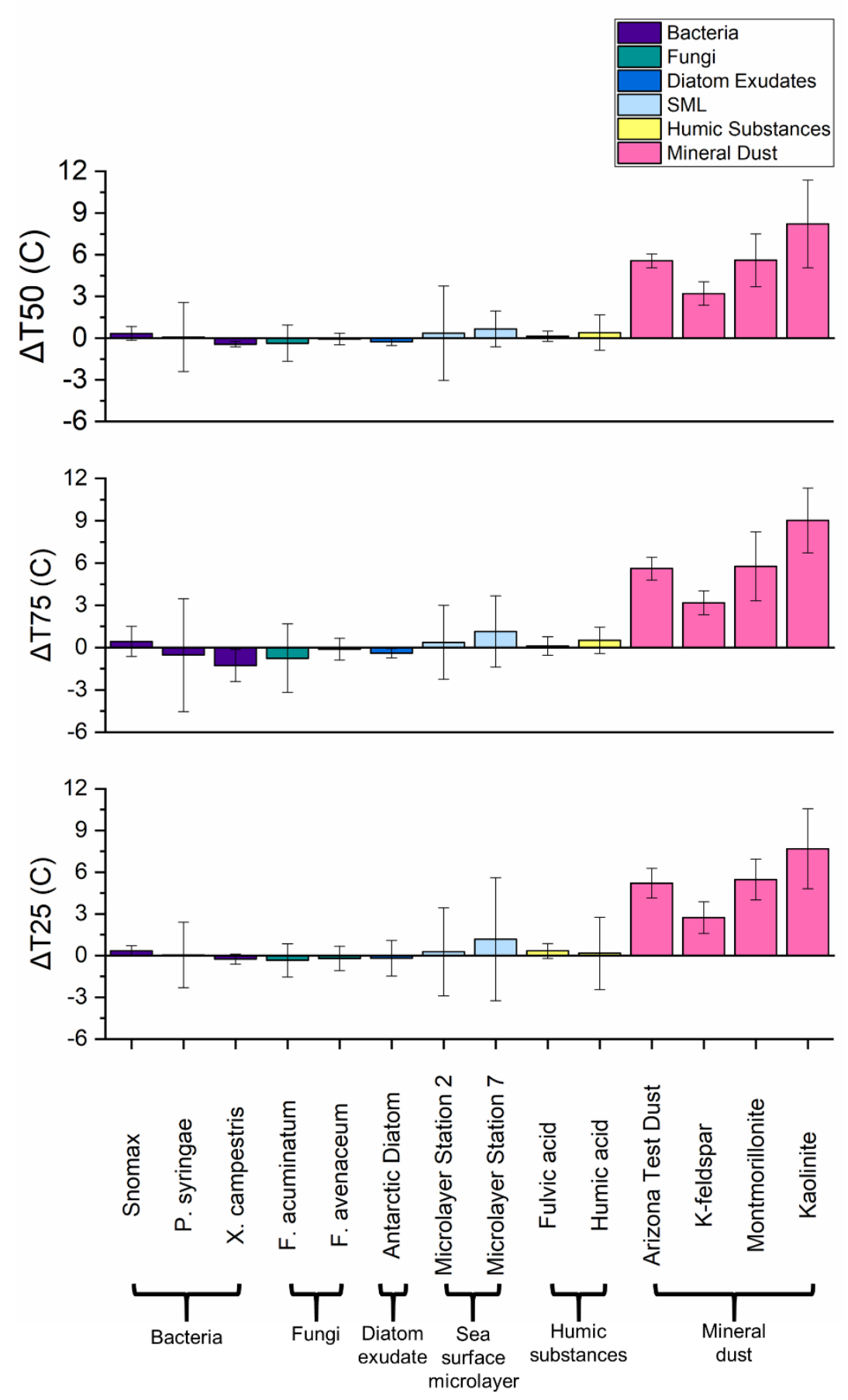

Figure 6. Change in the temperature at which $50 \%\left(\Delta \boldsymbol{T}_{50}\right), 75 \%\left(\Delta \boldsymbol{T}_{75}\right)$, and $25 \%\left(\Delta \boldsymbol{T}_{25}\right)$ of sample droplets were frozen between samples with $\left(\mathrm{NH}_{4}\right)_{2} \mathrm{SO}_{4}$ added and samples without $\left(\mathrm{NH}_{4}\right)_{2} \mathrm{SO}_{4}$ added. Error bars represent the $95 \%$ confidence interval calculated using the Student's $T$ distribution. Freezing data have been corrected for freezing point depression by 0.05 M $\left(\mathrm{NH}_{4}\right)_{2} \mathrm{SO}_{4}$. 
https://doi.org/10.5194/acp-2021-245

Preprint. Discussion started: 25 March 2021

(c) Author(s) 2021. CC BY 4.0 License.

(c) (i)

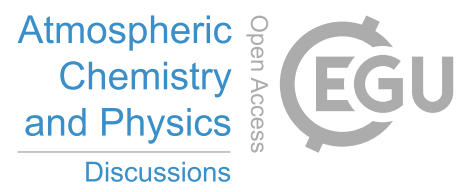

\subsection{Effects of $\left(\mathrm{NH}_{4}\right)_{2} \mathrm{SO}_{4}$ on ice nucleation by mineral dusts}

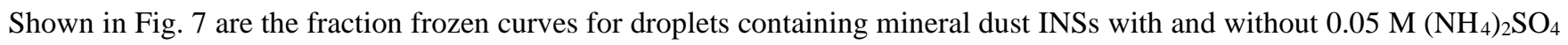

290 and fraction frozen curves for ultrapure water (laboratory blanks). The laboratory blanks froze at significantly colder temperatures than the mineral dust samples, indicating that the mineral dust was responsible for ice nucleation in the droplets containing mineral dust. 

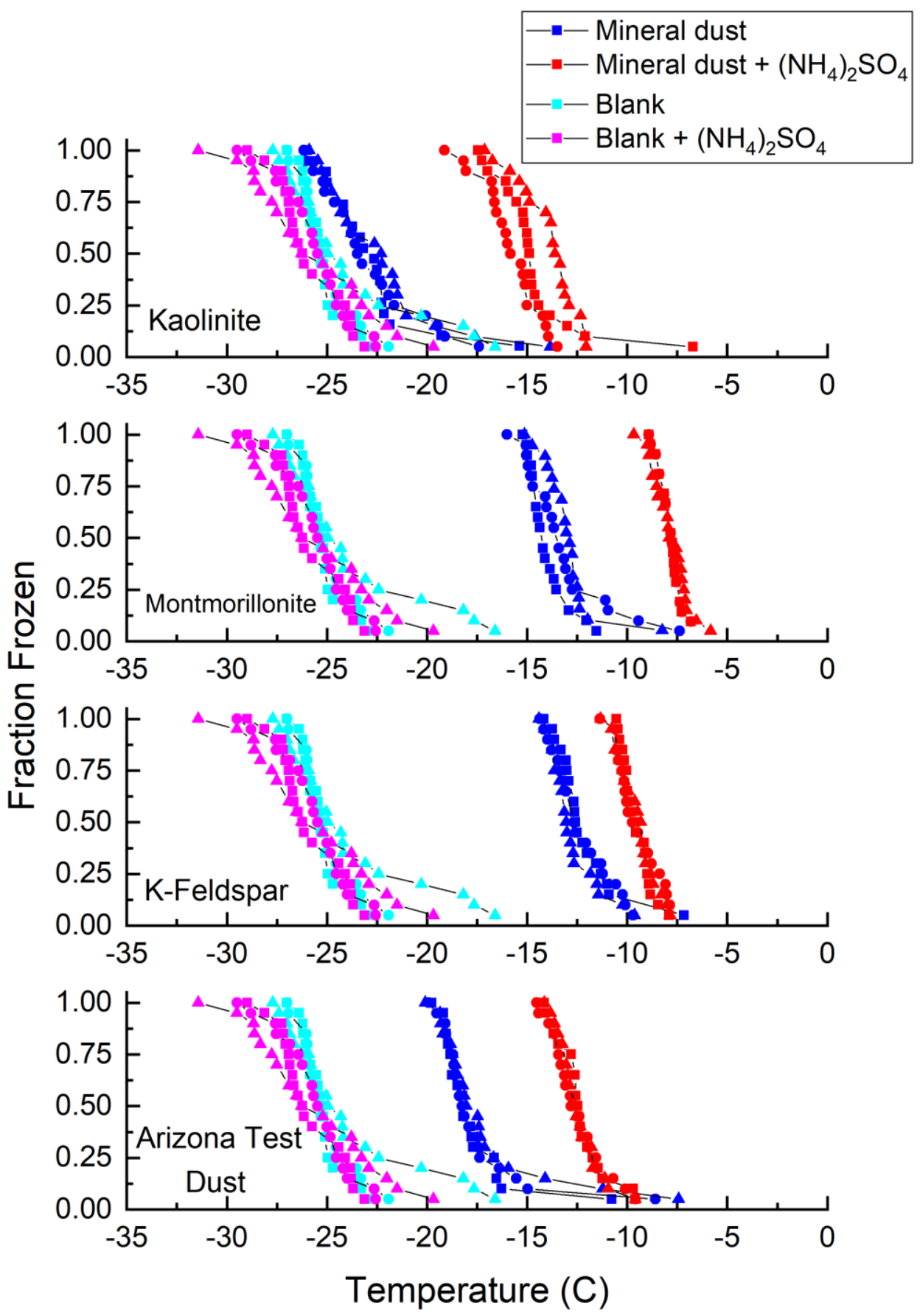

Figure 7. Fraction of droplets frozen as a function of temperature for samples of Kaolinite (top), montmorillonite, K-feldspar, and Arizona Test Dust (bottom) with (red) and without (blue) $0.05 \mathrm{M}\left(\mathrm{NH}_{4}\right)_{2} \mathrm{SO}_{4}$ compared with an ultrapure water control for each sample with (pink) and without (cyan) 0 . $\left(\mathrm{NH}_{4}\right)_{2} \mathrm{SO}_{4}$. Different symbols with the same color represent different trials. Freezing data have been corrected for freezing point depression by $0.05 \mathrm{M}\left(\mathrm{NH}_{4}\right)_{2} \mathrm{SO}_{4}$. 
The fraction frozen curves for droplets containing K-rich feldspar dust in the presence of $\left(\mathrm{NH}_{4}\right)_{2} \mathrm{SO}_{4}$ were shifted to warmer temperatures than those without $\left(\mathrm{NH}_{4}\right)_{2} \mathrm{SO}_{4}$ (Fig. 6, 7). The $\Delta T_{50}, \Delta T_{25}$, and $\Delta T_{75}$ values for K-feldspar were $3.21 \pm 0.83{ }^{\circ} \mathrm{C}$, $2.73 \pm 1.15{ }^{\circ} \mathrm{C}$, and $3.17 \pm 0.84{ }^{\circ} \mathrm{C}$, respectively. These results are consistent with previous studies that investigated the effect of $\left(\mathrm{NH}_{4}\right)_{2} \mathrm{SO}_{4}$ on freezing of $\mathrm{K}$-feldspar (Kumar et al., 2018; Whale et al., 2018).

The fraction frozen curves for droplets containing ATD in the presence of $\left(\mathrm{NH}_{4}\right)_{2} \mathrm{SO}_{4}$ were also shifted to warmer temperatures than those without $\left(\mathrm{NH}_{4}\right)_{2} \mathrm{SO}_{4}$ (Fig. 6, 7). The $\Delta T_{50}, \Delta T_{25}$, and $\Delta T_{75}$ values for ATD were $5.56 \pm 0.49^{\circ} \mathrm{C}, 5.21$ $\pm 1.07{ }^{\circ} \mathrm{C}$, and $5.60 \pm 0.82{ }^{\circ} \mathrm{C}$, respectively. In contrast to these results, Whale et al. (2018) found that $\left(\mathrm{NH}_{4}\right)_{2} \mathrm{SO}_{4}$ did not significantly change the freezing temperatures of ATD. Possible reasons for the differences between these results include: 1) Differences in $\left(\mathrm{NH}_{4}\right)_{2} \mathrm{SO}_{4}$ concentrations (0.05M in our study compared with $0.015 \mathrm{M}$ in Whale et. al. 2018), 2) the exposure time of ATD particles to $\left(\mathrm{NH}_{4}\right)_{2} \mathrm{SO}_{4}$ before freezing experiments are performed (shorter interaction times between $\left(\mathrm{NH}_{4}\right)_{2} \mathrm{SO}_{4}$ and ATD were used in the current study compared to Whale et. al. 2018), and 3) differences in the composition of

310 the ATD sample used. Although the same type of ATD was used in both studies, there can be variability in ATD composition from batch to batch (Kaufmann et al., 2016).

The fraction frozen curves for droplets containing montmorillonite in the presence of $\left(\mathrm{NH}_{4}\right)_{2} \mathrm{SO}_{4}$ were also shifted to warmer temperatures than those without $\left(\mathrm{NH}_{4}\right)_{2} \mathrm{SO}_{4}$ (Fig. 6, 7). The $\Delta T_{50}, \Delta T_{25}$, and $\Delta T_{75}$ values for montmorillonite were $5.61 \pm$

$3151.90{ }^{\circ} \mathrm{C}, 5.47 \pm 1.47{ }^{\circ} \mathrm{C}$, and $5.77 \pm 1.61{ }^{\circ} \mathrm{C}$, respectively. No previous studies examined the effects of $\left(\mathrm{NH}_{4}\right)_{2} \mathrm{SO}_{4}$ on montmorillonite. However, the effects of ammonia gas on the ice nucleation properties of montmorillonite in the deposition mode have been studied and exposure to ammonia gas has been shown to enhance the ice nucleation activity of montmorillonite (Salam et al., 2007).

320 Lastly, the fraction frozen curves for droplets containing kaolinite in the presence of $\left(\mathrm{NH}_{4}\right)_{2} \mathrm{SO}_{4}$ were also shifted to warmer temperatures than those without $\left(\mathrm{NH}_{4}\right)_{2} \mathrm{SO}_{4}$ (Fig. 6, 7). The $\Delta T_{50}, \Delta T_{25}$, and $\Delta T_{75}$ values for kaolinite were $8.22 \pm 3.15{ }^{\circ} \mathrm{C}$, $7.69 \pm 2.88{ }^{\circ} \mathrm{C}$, and $9.02 \pm 2.30{ }^{\circ} \mathrm{C}$, respectively. The observed increase in ice nucleation activity in the presence of $\left(\mathrm{NH}_{4}\right)_{2} \mathrm{SO}_{4}$ is consistent with previous studies that investigated its effect on the immersion freezing of kaolinite (Kumar et al., 2019b).

\section{$325 \quad 3.3$ Mechanisms}

The K-rich feldspar sample studied here consists of $85 \%$ microcline $\left(\mathrm{KAlSi}_{3} \mathrm{O}_{8}\right)$ and $15 \%$ albite $\left(\mathrm{NaAlSi}_{3} \mathrm{O}_{8}\right)$. Since, in general, microcline is a better ice nucleus than albite, microcline is likely responsible for ice nucleation in our experiments (Harrison et al., 2016; Peckhaus et al., 2016b; Zolles et al., 2015; Atkinson et al., 2013; Whale et al., 2017). Microcline is composed of $\mathrm{AlO}_{4}^{-}$and $\mathrm{SiO}_{4}$ tetrahedral groups, with the negative charge of $\mathrm{AlO}_{4}^{-}$being compensated by $\mathrm{K}^{+}$in the crystal 
lattice. When microcline is exposed to $\left(\mathrm{NH}_{4}\right)_{2} \mathrm{SO}_{4}$, ion exchange can occur between $\mathrm{NH}_{4}^{+}$and $\mathrm{K}^{+}$(Gülgönül et al., 2012; Nash and Marshall, 1957; Stumm and Morgan, 1971; Barker, 1964):

$\mathrm{KAlSi}_{3} \mathrm{O}_{8}+\mathrm{NH}_{4}{ }^{+} \leftrightarrow \mathrm{NH}_{4} \mathrm{AlSi}_{3} \mathrm{O}_{8}+\mathrm{K}^{+}$

One possible explanation for the strong positive effect of $\left(\mathrm{NH}_{4}\right)_{2} \mathrm{SO}_{4}$ on the ice nucleation ability of K-rich feldspar is ion exchange between $\mathrm{NH}_{4}^{+}$in solution and parent $\mathrm{K}^{+}$in the microcline to form surfaces more conducive to ice nucleation.

In our experiments, the surface of K-rich feldspar was negatively charged since the $\mathrm{pH}$ of the solutions were above the point of zero charge (PZC) of K-rich feldspar ( 1-2) (Kosmulski, 2009). Under these conditions $\mathrm{NH}_{4}^{+}$is likely to adsorb to the negatively charged K-rich feldspar surfaces (Kumar et al., 2018; Nash and Marshall, 1957). Therefore, another possible explanation for the strong positive effect of $\left(\mathrm{NH}_{4}\right)_{2} \mathrm{SO}_{4}$ on the ice nucleation ability of K-rich feldspar is the adsorption of $\mathrm{NH}_{4}^{+}$on the K-rich feldspar surface, which can potentially affect the orientation of water molecules near the mineral surface and enhance ice nucleation (Kumar et al., 2018; Anim-Danso et al., 2016).

Kaolinite $\left(\mathrm{Al}_{2} \mathrm{Si}_{2} \mathrm{O}_{5}(\mathrm{OH})_{5}\right.$, negatively charged with $\left.\mathrm{PZC} \sim 3-6\right)$ only offers adsorption of $\mathrm{NH}_{4}^{+}$due to lack of chargebalancing cation, while ion exchange and absorption of $\mathrm{NH}_{4}^{+}$are both possible on feldspars. Since feldspars and kaolinite constitute a major part of ATD, they may explain the enhanced ice nucleation ability of ATD in the presence of $\left(\mathrm{NH}_{4}\right)_{2} \mathrm{SO}_{4}$. Although PZC values for montmorillonite can range from 1-10, they are typically in the range of 2-4 which is less than the $\mathrm{pH}$ of the solution (Kosmulski, 2009, 2020). Hence $\mathrm{NH}_{4}^{+}$is also likely to adsorb to a negatively charged surface of montmorillonite, which can potentially enhance ice nucleation at the mineral surface, as discussed above. In contrast, these mechanisms do not appear to be important for ice nucleation of the non-mineral dust INSs studied here.

The ice nucleation activity in $P$. syringae and $X$. campestris, the two bacteria studied here, has been successfully attributed to proteins located on the outer cell membrane (Kawahara, 2002; Warren and Corotto, 1989; Wolber and Warren, 1989; Failor et al., 2017; Pummer et al., 2015; Zhao and Orser, 1990). The proteins have repeating units containing threonine amino acids that provide a template for ice (Kawahara, 2002; Warren and Corotto, 1989; Wolber and Warren, 1989; Gurian-Sherman and 355 Lindow, 1993; Hew and Yang, 1992; Zhao and Orser, 1990; Graether and Jia, 2001; Garnham et al., 2011). Either $\left(\mathrm{NH}_{4}\right)_{2} \mathrm{SO}_{4}$ molecules in solution do not interact with the repeating unit of the protein, or any interactions that occur (e.g., adsorption of ions or the induction of small conformational changes) do not lead to a significant enhancement of the ice nucleation activity of these proteins.

360 In comparison to $P$. syringae and $X$. campestris, the molecules responsible for ice nucleation in the other non-mineral dust samples are not well studied and their precise identities and mechanisms for ice nucleation are not well understood. Regardless of the specific molecules an mechanisms responsible for the ice nucleation activity of the studied non-mineral 
dust INSs, our results show that either the non-mineral dust INSs studied do not interact with the $\left(\mathrm{NH}_{4}\right)_{2} \mathrm{SO}_{4}$ molecules in solution, or the mechanisms of ice nucleation by these INSs are such that any interactions that may occur (e.g. adsorption of ions or the induction of small conformational changes) do not have a significant impact, since changes observed in ice nucleation activity of the large majority of the non-mineral dust INSs were less than the uncertainty of our measurements.

\section{Conclusions}

In this work, immersion freezing experiments were performed using the droplet freezing technique to investigate the effects of a low concentration $(0.05 \mathrm{M})$ of $\left(\mathrm{NH}_{4}\right)_{2} \mathrm{SO}_{4}$, an atmospherically relevant inorganic solute, on the ice nucleating ability of a range of non-mineral dust INSs of atmospheric relevance. These included bacteria, fungi, exudates from sea ice diatoms collected in Antarctica, INSs from the sea surface microlayer collected in the Arctic, and humic and fulvic acid. For the majority of these non-mineral dust INSs, $\Delta T_{50}, \Delta T_{25}$, and $\Delta T_{75}$ values were less than the uncertainty in the measurements, indicating no change in freezing temperature in the presence of $\left(\mathrm{NH}_{4}\right)_{2} \mathrm{SO}_{4}$. Only two samples (X. campestris and Antarctic diatom exudates) showed significantly negative values of $\Delta T_{50}$ and/or $\Delta T_{75}$. In no case was a statistically significant positive $\Delta T_{50}, \Delta T_{25}$, or $\Delta T_{75}$ observed for a non-mineral dust INS, consistent with $\left(\mathrm{NH}_{4}\right)_{2} \mathrm{SO}_{4}$ either having no effect on or very slightly decreasing the ice nucleation ability of non-mineral dust INSs. As a comparison, we also investigated the effects of $\left(\mathrm{NH}_{4}\right)_{2} \mathrm{SO}_{4}$ on the ice nucleating ability of four types of mineral dust (ATD, K-rich feldspar, montmorillonite, and kaolinite). All mineral dusts had significantly positive values for $\Delta T_{50}, \Delta T_{25}$, and $\Delta T_{75}$ between $3{ }^{\circ} \mathrm{C}$ and $9{ }^{\circ} \mathrm{C}$, indicating that the addition of $\left(\mathrm{NH}_{4}\right)_{2} \mathrm{SO}_{4}$ enhances the ice nucleation activity of these mineral dust species. The different responses of mineral dust and non-mineral dust INSs to the addition of $\left(\mathrm{NH}_{4}\right)_{2} \mathrm{SO}_{4}$ suggest that they have different mechanisms of ice nucleation and/or different interactions with the solute at the ice nucleating surface. This is supported by the existing literature on the mechanisms of ice nucleation by mineral dusts, particularly K-rich feldspar, and proteins found in the studied bacteria $P$. syringae and $X$. campestris.

385 Our results suggest that the freezing temperature response of samples of unknown composition to the addition of $\left(\mathrm{NH}_{4}\right)_{2} \mathrm{SO}_{4}$ could potentially be used as a "fingerprint" or assay for the presence of mineral dust INSs in atmospheric samples. In addition, our results suggest that the relative importance of mineral dust to non-mineral dust INS for ice nucleation in mixedphase clouds could increase as these particles become coated with $\left(\mathrm{NH}_{4}\right)_{2} \mathrm{SO}_{4}$ in the atmosphere. Furthermore, our results provide additional evidence that the ice nucleating ability of mineral dust INSs in the immersion freezing mode increases when coated with $\left(\mathrm{NH}_{4}\right)_{2} \mathrm{SO}_{4}$, and hence this process should be included in models used to predict concentrations of INSs in mixed-phase clouds. On the other hand, this process can be ignored for non-mineral dust INSs.

Author contribution: SEW, JY, and AKB planned the experiments. SW conducted the experiments and prepared the initial paper draft. CX assisted with the experiments. PA provided the X. campestris strain. VEI collected the SML samples. JC 
prepared all bacterial and fungal cultures. SEW, AK, YX, JY, and AKB contributed to the interpretation of the results. SEW, AK, YX, and AKB wrote the manuscript. All co-authors reviewed and provided comments on the paper.

Competing interests: The authors declare that they have no conflict of interest Raymond for collecting and providing the Antarctic sea ice diatom exudate sample.

\section{References}

Ahern, H. E., Walsh, K. A., Hill, T. C. J., and Moffett, B. F.: Fluorescent pseudomonads isolated from Hebridean cloud and rain water produce biosurfactants but do not cause ice nucleation, 4, 115-124, https://doi.org/10.5194/bgd-3-1561-2006, 4052007.

Alpert, P. A., Aller, J. Y., and Knopf, D. A.: Initiation of the ice phase by marine biogenic surfaces in supersaturated gas and supercooled aqueous phases, Phys. Chem. Chem. Phys., 13, 19882-19894, https://doi.org/10.1039/c1cp21844a, 2011.

Amato, P., Parazols, M., Sancelme, M., Laj, P., Mailhot, G., and Delort, A.-M.: Microorganisms isolated from the water phase of tropospheric clouds at the Puy de Dôme: major groups and growth abilities at low temperatures, FEMS Microbiol.

410 Ecol., 59, 242-254, https://doi.org/10.1111/j.1574-6941.2006.00199.x, 2007.

Amato, P., Joly, M., Schaupp, C., Attard, E., Möhler, O., Morris, C. E., Brunet, Y., and Delort, A.-M.: Survival and ice nucleation activity of bacteria as aerosols in a cloud simulation chamber, Atmos. Chem. Phys., 15, 6455-6465, https://doi.org/10.5194/acp-15-6455-2015, 2015.

Anim-Danso, E., Zhang, Y., and Dhinojwala, A.: Surface charge affects the structure of interfacial ice, J. Phys. Chem. C, 415 120, 3741-3748, https://doi.org/10.1021/acs.jpcc.5b08371, 2016.

Ansmann, A., Tesche, M., Seifert, P., Althausen, D., Engelmann, R., Fruntke, J., Wandinger, U., Mattis, I., and Müller, D.: Evolution of the ice phase in tropical altocumulus: SAMUM lidar observations over Cape Verde, J. Geophys. Res., 114, D17208, https://doi.org/10.1029/2008JD011659, 2009.

Atkins, P. and de Paula, J.: Atkins’ Physical Chemistry, 10th Editi., Oxford University Press, Oxford, 2014.

420 Atkinson, J. D., Murray, B. J., Woodhouse, M. T., Whale, T. F., Baustian, K. J., Carslaw, K. S., Dobbie, S., O’Sullivan, D., and Malkin, T. L.: The importance of feldspar for ice nucleation by mineral dust in mixed-phase clouds, Nature, 498, 355358, https://doi.org/10.1038/nature12278, 2013.

Attard, E., Yang, H., Delort, A.-M., Amato, P., Pöschl, U., Glaux, C., Koop, T., and Morris, C. E.: Effects of atmospheric conditions on ice nucleation activity of Pseudomonas, Atmos. Chem. Phys, 12, 10667-10677, https://doi.org/10.5194/acp-

Augustin-Bauditz, S., Wex, H., Kanter, S., Ebert, M., Niedermeier, D., Stolz, F., Prager, A., and Stratmann, F.: The 
immersion mode ice nucleation behavior of mineral dusts: A comparison of different pure and surface modified dusts, Geophys. Res. Lett., 41, 7375-7382, https://doi.org/10.1002/2014GL061317, 2014.

Barker, D.: Ammonium in alkali feldspars, Am. Mineral., 49, 851-858, 1964.

Blanchard, D. C.: Sea-to-air transport of surface active material, Sci. Sci., 146, 396-397, https://doi.org/10.1126/science.146.3642.396, 1964.

Borduas-Dedekind, N., Ossola, R., David, R. O., Boynton, L. S., Weichlinger, V., Kanji, Z. A., and McNeill, K.: Photomineralization mechanism changes the ability of dissolved organic matter to activate cloud droplets and to nucleate ice crystals, Atmos. Chem. Phys., 19, 12397-12412, https://doi.org/10.3929/ethz-b-000372246, 2019.

Broadley, S. L., Murray, B. J., Herbert, R. J., Atkinson, J. D., Dobbie, S., Malkin, T. L., Condliffe, E., and Neve, L.: Immersion mode heterogeneous ice nucleation by an illite rich powder representative of atmospheric mineral dust, Atmos. Chem. Phys., 12, 287-307, https://doi.org/10.5194/acp-12-287-2012, 2012.

Burkert-Kohn, M., Wex, H., Welti, A., Hartmann, S., Grawe, S., Hellner, L., Herenz, P., Atkinson, J. D., Stratmann, F., and Kanji, Z. A.: Leipzig Ice Nucleation chamber Comparison (LINC): Intercomparison of four online ice nucleation counters, Atmos. Chem. Phys., 17, 11683-11705, https://doi.org/10.5194/acp-17-11683-2017, 2017.

Burrows, S. M., Butler, T., Jöckel, P., Tost, H., Kerkweg, A., Pöschl, U., and Lawrence, M. G.: Bacteria in the global atmosphere - Part 2: Modeling of emissions and transport between different ecosystems, Atmos. Chem. Phys., 9, 92819297, https://doi.org/10.5194/acp-9-9281-2009, 2009.

Chernoff, D. I. and Bertram, A. K.: Effects of sulfate coatings on the ice nucleation properties of a biological ice nucleus and several types of minerals, J. Geophys. Res., 115, D20205, https://doi.org/10.1029/2010JD014254, 2010.

Coluzza, I., Creamean, J., Rossi, M. J., Wex, H., Alpert, P. A., Bianco, V., Boose, Y., Dellago, C., Felgitsch, L., FröhlichNowoisky, J., Herrmann, H., Jungblut, S., Kanji, Z. A., Menzl, G., Moffett, B., Moritz, C., Mutzel, A., Pöschl, U., Schauperl, M., Scheel, J., Stopelli, E., Stratmann, F., Grothe, H., and Schmale, D. G.: Perspectives on the future of ice nucleation research: Research needs and unanswered questions identified from two international workshops, Atmosphere (Basel)., 8, 138, https://doi.org/10.3390/atmos8080138, 2017.

David, R. O., Marcolli, C., Fahrni, J., Qiu, Y., Perez Sirkin, Y. A., Molinero, V., Mahrt, F., Brühwiler, D., Lohmann, U., and Kanji, Z. A.: Pore condensation and freezing is responsible for ice formation below water saturation for porous particles, Proc. Natl. Acad. Sci., 116, 8184-8189, https://doi.org/10.1073/pnas.1813647116, 2019.

Delany, A. C., Claire Delany, A., Parkin, D. W., Griffin, J. J., Goldberg, E. D., and Reimann, B. E. F.: Airborne dust collected at Barbados, Geochim. Cosmochim. Acta, 31, 885-909, https://doi.org/10.1016/s0016-7037(67)80037-1, 1967.

DeMott, P. J., Hill, T. C. J., McCluskey, C. S., Prather, K. A., Collins, D. B., Sullivan, R. C., Ruppel, M. J., Mason, R. H., Irish, V. E., Lee, T., Hwang, C. Y., Rhee, T. S., Snider, J. R., McMeeking, G. R., Dhaniyala, S., Lewis, E. R., Wentzell, J. J. B., Abbatt, J., Lee, C., Sultana, C. M., Ault, A. P., Axson, J. L., Martinez, M. D., Venero, I., Santos-Figueroa, G., Stokes, M. D., Deane, G. B., Mayol-Bracero, O. L., Grassian, V. H., Bertram, T. H., Bertram, A. K., Moffett, B. F., and Franc, G. D.: 
https://doi.org/10.1073/pnas.1514034112, 2016.

Desnos, H., Bruyère, P., Louis, G., Buff, S., and Baudot, A.: Ice induction using Snomax® in the dimethyl-sulfoxidecontaining aqueous solution for DSC experiments, Thermochim. Acta, 692, 178734, https://doi.org/10.1016/j.tca.2020.178734, 2020.

465 Eastwood, M. L., Cremel, S., Gehrke, C., Girard, E., and Bertram, A. K.: Ice nucleation on mineral dust particles: Onset conditions, nucleation rates and contact angles, J. Geophys. Res., 113, D22203, https://doi.org/10.1029/2008JD010639, 2008 .

Failor, K. C., Schmale, D. G., Vinatzer, B. A., and Monteil, C. L.: Ice nucleation active bacteria in precipitation are genetically diverse and nucleate ice by employing different mechanisms, ISME J., 11, 2740-2753, https://doi.org/10.1038/ismej.2017.124, 2017.

Falkovich, A. H., Ganor, E., and Rudich, Y.: Adsorption of organic compounds pertinent to urban environments onto mineral dust particles, J. Geophys. Res., 109, D02208, https://doi.org/10.1029/2003JD003919, 2004.

Fröhlich-Nowoisky, J., Kampf, C. J., Weber, B., Huffman, J. A., Pöhlker, C., Andreae, M. O., Lang-Yona, N., Burrows, S. M., Gunthe, S. S., Elbert, W., Su, H., Hoor, P., Thines, E., Hoffmann, T., Després, V. R., and Pöschl, U.: Bioaerosols in the 475 Earth system: Climate, health, and ecosystem interactions, Atmos. Res., 182, 346-376, https://doi.org/10.1016/j.atmosres.2016.07.018, 2016.

Ganor, E.: The composition of clay minerals transported to Israel as indicators of Saharan dust emission, Atmos. Environ. Part A, Gen. Top., 25A, 2657-2664, https://doi.org/10.1016/0960-1686(91)90195-D, 1991.

Garnham, C. P., Campbell, R. L., Walker, V. K., and Davies, P. L.: Novel dimeric $\beta$-helical model of an ice nucleation protein with bridged active sites, BMC Struct. Biol., 11, 36, https://doi.org/10.1186/1472-6807-11-36, 2011.

Glaccum, R. A. and Prospero, J. M.: Saharan aerosols over the tropical North Atlantic - Mineralogy, Mar. Geol., 37, 295321, https://doi.org/10.1016/0025-3227(80)90107-3, 1980.

Graber, E. R. and Rudich, Y.: Atmospheric Chemistry and Physics Atmospheric HULIS: How humic-like are they? A comprehensive and critical review, Atmos. Chem. Phys, 729-753 pp., 2006.

485 Graether, S. P. and Jia, Z.: Modeling Pseudomonas syringae ice-nucleation protein as a $\beta$-helical protein, Biophys. J., 80, 1169-1173, https://doi.org/10.1016/S0006-3495(01)76093-6, 2001.

Grossi, S. M., Kottmeierl, S. T., Moe, R. L., Taylor, G. T., and Sullivan, C. W.: Sea ice microbial communities. VI. Growth and primary production in bottom ice under graded snow cover, Mar. Ecol. Prog. Ser., 35, 153-164, 1987.

Gülgönül, İ., Karagüzel, C., Çınar, M., and Çelik, M. S.: Interaction of sodium ions with feldspar surfaces and its effect on

490 the selective separation of $\mathrm{Na}-$ and K-feldspars, Miner. Process. Extr. Metall. Rev., 33, 233-245, https://doi.org/10.1080/08827508.2011.562952, 2012.

Gurian-Sherman, D. and Lindow, S. E.: Bacterial ice nucleation: Significance and molecular basis, FASEB J., 7, 1338-1343, https://doi.org/10.1096/fasebj.7.14.8224607, 1993.

Harrison, A. D., Whale, T. F., Carpenter, M. A., Holden, M. A., Neve, L., O’Sullivan, D., Vergara Temprado, J., and 
Murray, B. J.: Not all feldspars are equal: A survey of ice nucleating properties across the feldspar group of minerals, Atmos. Chem. Phys., 16, 10927-10940, https://doi.org/10.5194/acp-16-10927-2016, 2016.

Hasegawa, Y., Ishihara, Y., and Tokuyama, T.: Bioscience, biotechnology, and biochemistry characteristics of ice-nucleation activity in Fusarium avenaceum IFO 7158, Biosci. Biotechnol. Biochem., 58, 2273-2274, https://doi.org/10.1271/bbb.58.2273, 1994.

500 Hew, C. L. and Yang, D. S. C.: Protein interaction with ice, Eur. J. Biochem., 203, 33-42, https://doi.org/10.1111/j.14321033.1992.tb19824.x, 1992.

Hinz, K. P., Trimborn, A., Weingartner, E., Henning, S., Baltensperger, U., and Spengler, B.: Aerosol single particle composition at the Jungfraujoch, J. Aerosol Sci., 36, 123-145, https://doi.org/10.1016/j.jaerosci.2004.08.001, 2005.

Hoose, C. and Möhler, O.: Heterogeneous ice nucleation on atmospheric aerosols: a review of results from laboratory experiments, Atmos. Chem. Phys., 12, 9817-9854, https://doi.org/10.5194/acp-12-9817-2012, 2012.

Ickes, L., Porter, G. C. E., Wagner, R., Adams, M. P., Bierbauer, S., Bertram, A. K., Bilde, M., Christiansen, S., Ekman, A. M. L., Gorokhova, E., Höhler, K., Kiselev, A. A., Leck, C., Möhler, O., Murray, B. J., Schiebel, T., Ullrich, R., and Salter, M. E.: The ice-nucleating activity of Arctic sea surface microlayer samples and marine algal cultures, Atmos. Chem. Phys., 20, 11089-11117, https://doi.org/10.5194/acp-20-11089-2020, 2020.

510 Irish, V. E., Elizondo, P., Chen, J., Chou, C., Charette, J., Lizotte, M., Ladino, L. A., Wilson, T. W., Gosselin, M., Murray, B. J., Polishchuk, E., Abbatt, J. P. D., Miller, L. A., and Bertram, A. K.: Ice-nucleating particles in Canadian Arctic seasurface microlayer and bulk seawater, Atmos. Chem. Phys, 17, 10583-10595, https://doi.org/10.5194/acp-17-10583-2017, 2017.

Irish, V. E., Hanna, S. J., Xi, Y., Boyer, M., Polishchuk, E., Ahmed, M., Chen, J., Abbatt, J. P. D., Gosselin, M., Chang, R., 515 Miller, L. A., and Bertram, A. K.: Revisiting properties and concentrations of ice-nucleating particles in the sea surface microlayer and bulk seawater in the Canadian Arctic during summer, Atmos. Chem. Phys, 19, 7775-7787, https://doi.org/10.5194/acp-19-7775-2019, 2019.

Joly, M., Attard, E., Sancelme, M., Deguillaume, L., Guilbaud, C., Morris, C. E., Amato, P., and Delort, A.-M.: Ice nucleation activity of bacteria isolated from cloud water, Atmos. Environ., 70, 392-400,

520 https://doi.org/10.1016/J.ATMOSENV.2013.01.027, 2013.

Kandler, K., Benker, N., Bundke, U., Cuevas, E., Ebert, M., Knippertz, P., Rodríguez, S., Schütz, L., and Weinbruch, S.: Chemical composition and complex refractive index of Saharan mineral dust at Izaña, Tenerife (Spain) derived by electron microscopy, Atmos. Environ., 41, 8058-8074, https://doi.org/10.1016/j.atmosenv.2007.06.047, 2007.

Kanji, Z. A. and Abbatt, J. P. D.: Ice nucleation onto Arizona Test Dust at cirrus temperatures: Effect of temperature and 525 aerosol size on onset relative humidity, J. Phys. Chem. A, 114, 935-941, https://doi.org/10.1021/jp908661m, 2010.

Kanji, Z. A., Ladino, L. A., Wex, H., Boose, Y., Burkert-Kohn, M., Cziczo, D. J., and Krämer, M.: Overview of ice nucleating particles, Meteorol. Monogr., 58, 1.1-1.33, https://doi.org/10.1175/AMSMONOGRAPHS-D-16-0006.1, 2017.

Kanji, Z. A., Sullivan, R. C., Niemand, M., DeMott, P. J., Prenni, A. J., Chou, C., Saathoff, H., and Möhler, O.: 
Heterogeneous ice nucleation properties of natural desert dust particles coated with a surrogate of secondary organic aerosol,

Atmos. Chem. Phys., 19, 5091-5110, https://doi.org/10.5194/acp-19-5091-2019, 2019.

Kaufmann, L., Marcolli, C., Hofer, J., Pinti, V., Hoyle, C. R., and Peter, T.: Ice nucleation efficiency of natural dust samples in the immersion mode, Atmos. Chem. Phys., 16, 11177-11206, https://doi.org/10.5194/acp-16-11177-2016, 2016.

Kawahara, H.: The structures and functions of ice crystal-controlling proteins from bacteria, https://doi.org/10.1016/S13891723(02)80185-2, 1 December 2002.

535 Kim, H. K., Orser, C., Lindow, S. C., and Sands, D. C.: Xanthomonas campestris pv. translucens strains active in ice nucleation, Plant Dis., 71, 994-997, 1987.

Knopf, D. A. and Koop, T.: Heterogeneous nucleation of ice on surrogates of mineral dust, J. Geophys. Res. Atmos., 111, D12201, https://doi.org/10.1029/2005JD006894, 2006.

Knopf, D. A., Wang, B., Laskin, A., Moffet, R. C., and Gilles, M. K.: Heterogeneous nucleation of ice on anthropogenic organic particles collected in Mexico City, Geophys. Res. Lett., 37, n/a-n/a, https://doi.org/10.1029/2010GL043362, 2010.

Knopf, D. A., Alpert, P. A., Wang, B., and Aller, J. Y.: Stimulation of ice nucleation by marine diatoms, Nat. Geosci., 4, 8890, https://doi.org/10.1038/ngeo1037, 2011.

Koop, T. and Murray, B. J.: A physically constrained classical description of the homogeneous nucleation of ice in water, J. Chem. Phys., 145, 211915, https://doi.org/10.1063/1.4962355, 2016.

545 Koop, T. and Zobrist, B.: Parameterizations for ice nucleation in biological and atmospheric systems, Phys. Chem. Chem. Phys., 11, 10839-10850, https://doi.org/10.1039/b914289d, 2009.

Koop, T., Luo, B., Tsias, A., and Peter, T.: Water activity as the determinant for homogeneous ice nucleation in aqueous solutions, Nature, 406, 611-614, https://doi.org/10.1038/35020537, 2000.

Kosmulski, M.: Surface Charging and Points of Zero Charge, CRC Press Taylor and Francis Group, 2009.

550 Kosmulski, M.: The pH dependent surface charging and points of zero charge. VIII. Update, https://doi.org/10.1016/j.cis.2019.102064, 1 January 2020.

Kulkarni, G., Sanders, C., Zhang, K., Liu, X., and Zhao, C.: Ice nucleation of bare and sulfuric acid-coated mineral dust particles and implication for cloud properties, J. Geophys. Res. Atmos., 119, 9993-10011, https://doi.org/10.1002/2014JD021567, 2014.

555 Kumar, A., Marcolli, C., Luo, B., and Peter, T.: Ice nucleation activity of silicates and aluminosilicates in pure water and aqueous solutions-Part 1: The K-feldspar microcline, Atmos. Chem. Phys, 18, 7057-7079, https://doi.org/10.5194/acp-187057-2018, 2018.

Kumar, A., Marcolli, C., and Peter, T.: Ice nucleation activity of silicates and aluminosilicates in pure water and aqueous solutions-Part 2: Quartz and amorphous silica, Atmos. Chem. Phys, 19, 6035-6058, https://doi.org/10.5194/acp-19-6035-

Kumar, A., Marcolli, C., and Peter, T.: Ice nucleation activity of silicates and aluminosilicates in pure water and aqueous solutions-Part 3: Aluminosilicates, Atmos. Chem. Phys, 19, 6059-6084, https://doi.org/10.5194/acp-19-6059-2019, 2019 b. 
Ladino, L. A., Yakobi-Hancock, J. D., Kilthau, W. P., Mason, R. H., Si, M., Li, J., Miller, L. A., Schiller, C. L., Huffman, J. A., Aller, J. Y., Knopf, D. A., Bertram, A. K., and Abbatt, J. P. D.: Addressing the ice nucleating abilities of marine aerosol:

A combination of deposition mode laboratory and field measurements, Atmos. Environ., 132, 1-10, https://doi.org/10.1016/J.ATMOSENV.2016.02.028, 2016.

Lide, R. D.: CRC Handbook of Chemistry and Physics, CRC Press Taylor and Francis Group, 2001.

Lindemann, J., Constantinidou, H. A., Barchet, W. R., and Upper, C. D.: Plants as sources of airborne bacteria, including ice nucleation-active bacteria, Applied and Environmental Microbiology, 1059-1063 pp., 1982.

Lindow, S. E., Lahue, E., Govindarajan, A. G., Panopoulos, N. J., and Gies, D.: Localization of ice nucleation activity and the iceC gene product in Pseudomonas syringae and Escherichia coli, Mol. Plant Microbe, 2, 262-272, 1989.

Link, N., Removski, N., Yun, J., Fleming, L. T., Nizkorodov, S. A., Bertram, A. K., and Al-Abadleh, H. A.: Dust-Catalyzed oxidative polymerization of catechol and its impacts on ice nucleation efficiency and optical properties, ACS Earth Sp. Chem., 4, 1127-1139, https://doi.org/10.1021/acsearthspacechem.0c00107, 2020.

575 Liss, P. S. and Duce, R. A.: The Sea Surface and Global Change, Cambridge University Press, https://doi.org/10.1017/cbo9780511525025, 1997.

Lüönd, F., Stetzer, O., Welti, A., and Lohmann, U.: Experimental study on the ice nucleation ability of size-selected kaolinite particles in the immersion mode, J. Geophys. Res., 115, D14201, https://doi.org/10.1029/2009JD012959, 2010.

Maki, L. R., Galyan, E. L., Chang-Chien, M.-M., and Caldwell, D. R.: Ice nucleation induced by Pseudomonas syringae, Appl. Microbiol., 28, 456-459, 1974.

Mccluskey, C. S., Hill, E. T. C. J., Sultana, C. M., Laskina, O., Trueblood, J., Santander, M. V., Beall, C. M., Michaud, J. M., Kreidenweis, S. M., Prather, K. A., Grassian, V., and Demott, P. J.: A mesocosm double feature: Insights into the chemical makeup of marine ice nucleating particles, J. Atmos. Sci., 75, 2405-2423, https://doi.org/10.1175/JAS-D-17$0155.1,2018$.

McNaughton, C. S., Clarke, A. D., Kapustin, V., Shinozuka, Y., Howell, S. G., Anderson, B. E., Winstead, E., Dibb, J., Scheuer, E., Cohen, R. C., Wooldridge, P., Perring, A., Huey, L. G., Kim, S., Jimenez, J. L., Dunlea, E. J., DeCarlo, P. F., Wennberg, P. O., Crounse, J. D., Weinheimer, A. J., and Flocke, F.: Observations of heterogeneous reactions between Asian pollution and mineral dust over the Eastern North Pacific during INTEX-B, Atmos. Chem. Phys., 9, 8283-8308, https://doi.org/10.5194/acp-9-8283-2009, 2009.

590 Möhler, O., Georgakopoulos, D. G., Morris, C. E., Benz, S., Ebert, V., Hunsmann, S., Saathoff, H., Schnaiter, M., and Wagner, R.: Heterogeneous ice nucleation activity of bacteria: new laboratory experiments at simulated cloud conditions, 5, 1425-1435, 2008.

Murray, B. J., O’Sullivan, D., Atkinson, J. D., and Webb, M. E.: Ice nucleation by particles immersed in supercooled cloud droplets, Chem. Soc. Rev., 41, 6519-6554, https://doi.org/10.1039/c2cs35200a, 2012.

595 Nash, V. E. and Marshall, C. E.: Cationic reactions of feldspar surfaces, Soil Sci. Soc. Am. J., 21, 149, https://doi.org/10.2136/sssaj1957.03615995002100020005x, 1957. 
O’Sullivan, D., Murray, B. J., Malkin, T. L., Whale, T. F., Umo, N. S., Atkinson, J. D., Price, H. C., Baustian, K. J., Browse, J., and Webb, M. E.: Ice nucleation by fertile soil dusts: relative importance of mineral and biogenic components, 14, 18531867, https://doi.org/10.5194/acp-14-1853-2014, 2014.

600 Peckhaus, A., Kiselev, A., Hiron, T., Ebert, M., and Leisner, T.: A comparative study of K-rich and Na/Ca-rich feldspar icenucleating particles in a nanoliter droplet freezing assay, Atmos. Chem. Phys., 16, 11477-11496, https://doi.org/10.5194/acp-16-11477-2016, 2016a.

Peckhaus, A., Kiselev, A., Hiron, T., Ebert, M., and Leisner, T.: A comparative study of K-rich and Na/Ca-rich feldspar icenucleating particles in a nanoliter droplet freezing assay, Atmos. Chem. Phys., 16, 11477-11496, https://doi.org/10.5194/acp-16-11477-2016, 2016 b.

Perkins, R. J., Gillette, S. M., Hill, T. C. J., and DeMott, P. J.: The labile nature of ice nucleation by Arizona Test Dust, ACS Earth Sp. Chem., 4, 133-141, https://doi.org/10.1021/acsearthspacechem.9b00304, 2020.

Petrikkou, E., Rodríguez, J. L., Cuenca-Estrella, M., Gómez, A., Molleja, A., and Mellado, E.: Inoculum standardization for antifungal susceptibility testing of filamentous fungi pathogenic for humans, J. Clin. Microbiol., 39, 1345-1347, https://doi.org/10.1128/JCM.39.4.1345-1347.2001, 2001.

Pinti, V.;, Marcolli, C.;, Zobrist, B.;, Hoyle, C. R.;, and Peter, T.: Ice nucleation efficiency of clay minerals in the immersion mode, Atmos. Chem. Phys., 12, 5859-5878, https://doi.org/10.3929/ethz-b-000052156, 2012.

Pouleur, S., Richard, C., Martin, J.-G., and Antoun, H.: Ice nucleation activity in Fusarium acuminatum and Fusarium avenaceum, Appl. Environ. Microbiol., 58, 2960-2964, 1992.

615 Pratt, K. A., DeMott, P. J., French, J. R., Wang, Z., Westphal, D. L., Heymsfield, A. J., Twohy, C. H., Prenni, A. J., and Prather, K. A.: In situ detection of biological particles in cloud ice-crystals, Nat. Geosci., 2, 398-401, https://doi.org/10.1038/ngeo521, 2009.

Prospero, J. M.: Long-range transport of mineral dust in the global atmosphere: Impact of African dust on the environment of the southeastern United States, Proc. Natl. Acad. Sci. U. S. A., 96, 3396-3403, https://doi.org/10.1073/pnas.96.7.3396, 1999.

Pummer, B. G., Budke, C., Augustin-Bauditz, S., Niedermeier, D., Felgitsch, L., Kampf, C. J., Huber, R. G., Liedl, K. R., Loerting, T., Moschen, T., Schauperl, M., Tollinger, M., Morris, C. E., Wex, H., Grothe, H., Pöschl, U., Koop, T., and Fröhlich-Nowoisky, J.: Ice nucleation by water-soluble macromolecules, Atmos. Chem. Phys, 15, 4077-4091, https://doi.org/10.5194/acp-15-4077-2015, 2015.

625 Raymond, J. A.: Distribution and partial characterization of ice-active molecules associated with sea-ice diatoms, Polar Biol., 23, 721-729, https://doi.org/10.1007/s003000000147, 2000.

Raymond, J. A. and Fritsen, C. H.: Semipurification and ice recrystallization inhibition activity of ice-active substances associated with antarctic photosynthetic organisms, Cryobiology, 43, 63-70, https://doi.org/10.1006/cryo.2001.2341, 2001.

Reischel, M. T. and Vali, G.: Freezing nucleation in aqueous electrolytes, 27, 414-427, https://doi.org/10.1111/j.21533490.1975.tb01692.x, 1975. 
Ren, Y., Bertram, A. K., and Patey, G. N.: Effects of inorganic ions on ice nucleation by the Al surface of kaolinite immersed in water, J. Phys. Chem. B, 124, 4605-4618, https://doi.org/10.1021/acs.jpcb.0c01695, 2020.

Richard, C., Martin, J.-G., and Pouleur, S.: Ice nucleation activity identified in some phytopathogenic Fusarium species, 77, 83-92, https://doi.org/10.7202/706104ar, 1996.

Rigg, Y. J., Alpert, P. A., and Knopf, D. A.: Sciences ess Atmospheric Chemistry and Physics Climate of the Past Geoscientific Instrumentation Methods and Data Systems Immersion freezing of water and aqueous ammonium sulfate droplets initiated by humic-like substances as a function of water activity, Atmos. Chem. Phys, 13, 6603-6622, https://doi.org/10.5194/acp-13-6603-2013, 2013.

Salam, A., Lohmann, U., and Lesins, G.: Ice nucleation of ammonia gas exposed montmorillonite mineral dust particles, Atmos. Chem. Phys., 7, 3923-3931, https://doi.org/10.5194/acp-7-3923-2007, 2007.

Schwidetzky, R., Lukas, M., YazdanYar, A., Kunert, A. T., Pöschl, U., Domke, K. F., Fröhlich-Nowoisky, J., Bonn, M., Koop, T., Nagata, Y., and Meister, K.: Specific Ion-Protein Interactions Influence Bacterial Ice Nucleation, Chem. - A Eur. J., chem.202004630, https://doi.org/10.1002/chem.202004630, 2021.

Seifi, T., Ketabchi, S., Aminian, H., Etebarian, H. R., and Kamali, M.: Investigation and comparison of the ice nucleation 645 activity in Fusarium avenaceum and Fusarium acuminatum, Int. J. Farming Allied Sci., 3, 518-528, 2014.

Shilling, J. E., Fortin, T. J., and Tolbert, M. A.: Depositional ice nucleation on crystalline organic and inorganic solids, J. Geophys. Res., 111, D12204, https://doi.org/10.1029/2005JD006664, 2006.

Stumm, W. and Morgan, J. J.: Aquatic Chemistry: An Introduction Emphasizing Chemical Equilibria in Natural Waters, Wiley-Interscience, New York, 1971.

650 Sullivan, R. C., Miñambres, L., Demott, P. J., Prenni, A. J., Carrico, C. M., Levin, E. J. T., and Kreidenweis, S. M.: Chemical processing does not always impair heterogeneous ice nucleation of mineral dust particles, Geophys. Res. Lett., 37, L24805, https://doi.org/10.1029/2010GL045540, 2010a.

Sullivan, R. C., Petters, M. D., DeMott, P. J., Kreidenweis, S. M., Wex, H., Niedermeier, D., Hartmann, S., Clauss, T., Stratmann, F., Reitz, P., Schneider, J., and Sierau, B.: Irreversible loss of ice nucleation active sites in mineral dust particles caused by sulphuric acid condensation, Atmos. Chem. Phys., 10, 11471-11487, https://doi.org/10.5194/acp-10-11471-2010, $2010 \mathrm{~b}$.

Tang, M., Cziczo, D. J., and Grassian, V. H.: Interactions of water with mineral dust aerosol: Water adsorption, hygroscopicity, cloud condensation, and ice nucleation, Chem. Rev., 116, 4205-4259, https://doi.org/10.1021/acs.chemrev.5b00529, 2016.

660 Tinsley, B., Rohrbaugh, R., and Hei, M.: Effects of image charges on the scavenging of aerosol particles by cloud droplets and on droplet charging and possible ice nucleation processes, J. Atmos. Sci., 57, 2118-2134, https://doi.org/10.1175/15200469(2000)057<2118:EOICOT>2.0.CO;2, 2000.

Tobo, Y., DeMott, P. J., Raddatz, M., Niedermeier, D., Hartmann, S., Kreidenweis, S. M., Stratmann, F., and Wex, H.: Impacts of chemical reactivity on ice nucleation of kaolinite particles: A case study of levoglucosan and sulfuric acid, 
Geophys. Res. Lett., 39, L19803, https://doi.org/10.1029/2012GL053007, 2012.

Usher, C. R., Michel, A. E., and Grassian, V. H.: Reactions on mineral dust, Chem. Rev., 103, 4883-49439, https://doi.org/10.1021/cr020657y, 2003.

Vaitilingom, M., Attard, E., Gaiani, N., Sancelme, M., Deguillaume, L., Flossmann, A. I., Amato, P., and Delort, A.-M.: Long-term features of cloud microbiology at the puy de Dôme (France), Atmos. Environ., 56, 88-100, https://doi.org/10.1016/j.atmosenv.2012.03.072, 2012.

Vali, G.: Quantitative evaluation of experimental results on the heterogeneous freezing nucleation of supercooled liquids, J. Atmos. Sci., 28, 402-409, https://doi.org/10.1175/1520-0469(1971)028<0402:QEOERA>2.0.CO;2, 1971.

Vali, G., Demott, P. J., Möhler, O., and Whale, T. F.: Technical Note: A proposal for ice nucleation terminology, Atmos. Chem. Phys, 15, 10263-10270, https://doi.org/10.5194/acp-15-10263-2015, 2015.

675 Wang, X., Sultana, C. M., Trueblood, J., Hill, T. C. J., Malfatti, F., Lee, C., Laskina, O., Moore, K. A., Beall, C. M., McCluskey, C. S., Cornwell, G. C., Zhou, Y., Cox, J. L., Pendergraft, M. A., Santander, M. V., Bertram, T. H., Cappa, C. D., Azam, F., DeMott, P. J., Grassian, V. H., and Prather, K. A.: Microbial control of sea spray aerosol composition: A tale of two blooms, ACS Cent. Sci., 1, 124-131, https://doi.org/10.1021/acscentsci.5b00148, 2015.

Warren, G. and Corotto, L.: The consensus sequence of ice nucleation proteins from Enuinia herbicola, Pseudomonas 680 fluorescens and Pseudomonas syringae, Gene, 85, 239-242, 1989.

Weng, L., Tessier, S. N., Smith, K., Edd, J. F., Stott, S. L., and Toner, M.: Bacterial Ice Nucleation in Monodisperse D2O and H2O-in-Oil Emulsions, 32, 9229-9236, https://doi.org/10.1021/acs.langmuir.6b02212, 2016.

Westbrook, C. D. and Illingworth, A. J.: Evidence that ice forms primarily in supercooled liquid clouds at temperatures > $-27^{\circ} \mathrm{C}$, Geophys. Res. Lett., 38, L14808, https://doi.org/10.1029/2011GL048021, 2011.

685 Wex, H., Demott, P. J., Tobo, Y., Hartmann, S., Rösch, M., Clauss, T., Tomsche, L., Niedermeier, D., and Stratmann, F.: Kaolinite particles as ice nuclei: Learning from the use of different kaolinite samples and different coatings, Atmos. Chem. Phys., 14, 5529-5546, https://doi.org/10.5194/acp-14-5529-2014, 2014.

Wex, H., Augustin-Bauditz, S., Boose, Y., Budke, C., Curtius, J., Diehl, K., Dreyer, A., Frank, F., Hartmann, S., Hiranuma, N., Jantsch, E., Kanji, Z. A., Kiselev, A., Koop, T., Möhler, O., Niedermeier, D., Nillius, B., Rösch, M., Rose, D., Schmidt, 690 C., Steinke, I., and Stratmann, F.: Intercomparing different devices for the investigation of ice nucleating particles using Snomax ${ }^{\circledR}$ as test substance, Atmos. Chem. Phys., 15, 1463-1485, https://doi.org/10.5194/acp-15-1463-2015, 2015.

Whale, T. F., Murray, B. J., O’Sullivan, D., Wilson, T. W., Umo, N. S., Baustian, K. J., Atkinson, J. D., Workneh, D. A., and Morris, G. J.: A technique for quantifying heterogeneous ice nucleation in microlitre supercooled water droplets, Atmos. Meas. Tech., 8, 2437-2447, https://doi.org/10.5194/amt-8-2437-2015, 2015.

695 Whale, T. F., Holden, M. A., Kulak, A. N., Kim, Y. Y., Meldrum, F. C., Christenson, H. K., and Murray, B. J.: The role of phase separation and related topography in the exceptional ice-nucleating ability of alkali feldspars, Phys. Chem. Chem. Phys., 19, 31186-31193, https://doi.org/10.1039/c7cp04898j, 2017.

Whale, T. F., Holden, M. A., Wilson, T. W., O’Sullivan, D., and Murray, B. J.: The enhancement and suppression of 
immersion mode heterogeneous ice-nucleation by solutes, Chem. Sci., 9, 4142-4151, https://doi.org/10.1039/c7sc05421a, 2018.

Wheeler, M. J., Mason, R. H., Steunenberg, K., Wagstaff, M., Chou, C., and Bertram, A. K.: Immersion freezing of supermicron mineral dust particles: Freezing results, testing different schemes for describing ice nucleation, and ice nucleation active site densities, J. Phys. Chem. A, 119, 4358-4372, https://doi.org/10.1021/jp507875q, 2015.

White, R. E.: Principles and practice of soil science: the soil as a natural resource, Wiley-Blackwell, Oxford, UK, 2009.

Wilson, T. W., Ladino, L. A., Alpert, P. A., Breckels, M. N., Brooks, I. M., Browse, J., Burrows, S. M., Carslaw, K. S., Huffman, J. A., Judd, C., Kilthau, W. P., Mason, R. H., McFiggans, G., Miller, L. A., Nájera, J. J., Polishchuk, E., Rae, S., Schiller, C. L., Si, M., Temprado, J. V., Whale, T. F., Wong, J. P. S., Wurl, O., Yakobi-Hancock, J. D., Abbatt, J. P. D., Aller, J. Y., Bertram, A. K., Knopf, D. A., and Murray, B. J.: A marine biogenic source of atmospheric ice-nucleating particles, Nature, 525, 234-238, https://doi.org/10.1038/nature14986, 2015.

Wolber, P. and Warren, G.: Bacterial ice-nucleation proteins, Trends Biochem. Sci., 14, 179-182, https://doi.org/10.1016/0968-0004(89)90270-3, 1989.

Wolf, M. J., Goodell, M., Dong, E., Dove, L. A., Zhang, C., Franco, L. J., Shen, C., Rutkowski, E. G., Narducci, D. N., Mullen, S., Babbin, A. R., and Cziczo, D. J.: A link between the ice nucleation activity and the biogeochemistry of seawater, Atmos. Chem. Phys., 20, 15341-15356, https://doi.org/10.5194/acp-20-15341-2020, 2020.

715 Xi, Y., Mercier, A., Kuang, C., Yun, J., Christy, A., Melo, L., Maldonado, M. T., Raymond, J. A., and Bertram, A. K.: Concentrations and properties of ice nucleating substances in exudates from Antarctic sea-ice diatoms, Environ. Sci. Process. Impacts, https://doi.org/10.1039/D0EM00398K, 2021.

Yun, J., Link, N., Kumar, A., Shchukarev, A., Davidson, J., Lam, A., Walters, C., Xi, Y., Boily, J. F., and Bertram, A. K.: Surface composition dependence on the ice nucleating ability of potassium-rich feldspar, ACS Earth Sp. Chem., 4, 873-881, https://doi.org/10.1021/acsearthspacechem.0c00077, 2020.

Zhao, J. and Orser, C. S.: Conserved repetition in the ice nucleation gene inaX from Xanthomonas campestris pv. translucens, Mol. Genet. Genomics, 223, 163-166, 1990.

Zobrist, B., Marcolli, C., Peter, T., and Koop, T.: Heterogeneous ice nucleation in aqueous solutions: The role of water activity, J. Phys. Chem. A, 112, 3965-3975, https://doi.org/10.1021/jp7112208, 2008.

725 Zolles, T., Burkart, J., Häusler, T., Pummer, B., Hitzenberger, R., and Grothe, H.: Identification of ice nucleation active sites on feldspar dust particles, J. Phys. Chem. A, 119, 2692-2700, https://doi.org/10.1021/jp509839x, 2015. 